\title{
Macro-Prudential Policies to Mitigate Financial System Vulnerabilities
}

\author{
By \\ Stijn Claessens, Swati R. Ghosh, and Roxana Mihet ${ }^{*}$
}

\begin{abstract}
Macro-prudential policies (MaPP), aimed at reducing systemic financial risk, have become part of the toolkit of policy makers in many emerging markets (EMs) and some advanced countries (ACs). We review the analytical foundations for such policies. We then use panel data regression to analyze changes in balance sheets of some 2800 banks in 48 countries over 2000-2010 to identify those MaPP most effective in reducing financial cycles. We find that debt-to-income caps, loan-to-value ratios, and limits on credit growth foreign currency lending are effective in reducing leverage, asset and non-core to core liabilities growth during boom times, while countercyclical buffers (such as reserve requirements, limits on profit distribution, and dynamic provisioning) help mitigate declines in bank leverage and asset growth in adverse times. We conclude that MaPP can be important elements of the policy toolkit aimed at overall systemic risk mitigation, especially for EMs exposed to international shocks, but need to be properly designed and calibrated.
\end{abstract}

\footnotetext{
* Research Department, International Monetary Fund, Poverty Reduction and Economic Management Vice Presidency, World Bank, and Oxford University respectively. Prepared for the NIPFP-DEA-JIMF conference Rajasthan, India, December 12-13, 2012. The authors are grateful to Amar Bhattacharya for extensive discussions, and Tito Cordella and John Muellbauer for very helpful comments and suggestions on an earlier version of the paper. The views expressed here are those of the authors and should not be attributed to the IMF or the World Bank, or their respective Executive Directors or Management.

Email addresses: sclaessens@imf.org, sghosh@worldbank.org, roxana.mihet@economics.ox.ac.uk.
} 


\section{INTRODUCTION}

This paper analyzes the use of macro-prudential policies (MaPP) aimed at reducing vulnerabilities in banking systems, with a special focus on their use in and for emerging markets (EMs). ${ }^{1}$ Recent events have highlighted the high costs of financial crises. More generally, the potential for instability arising from the financial system-whether from excessiveness in cycles or from spillovers through interconnectedness-is increasingly recognized recently. Due also to policy research efforts, notably at the BIS, it has started a call for MaPP to complement micro-prudential regulations and traditional macroeconomic management policies, notably monetary policy and fiscal policy, to help contain (the buildup of) systemic risks and achieve greater financial stability, and in this way reduce adverse consequences of financial volatility - including from financial crises - for the real economy.

While many of the analyses to date have been motivated by the (ongoing) crisis in advanced countries (ACs), EMs have had much greater experiences with macro-prudential policies in recent years, in part as they have had more pronounced business and financial cycles, due in part to their greater exposures to volatile international capital flows, commodity price shocks, and other risks. In this context, there is much to learn for ACs from EMs on the effectiveness of MaPP. And, there are of course lessons for EMs themselves.

The paper asks the following questions. What are the specific market failures and externalities that can motivate the use of MaPP to reduce systemic risks? What are the key policy measures, both traditional and MaPP, available to countries to reduce systemic risk and its impacts? What MaPP policies have countries actually used and what is the evidence to date on the effectiveness of different MaPP to reduce financial system vulnerabilities? On the basis of its analytics and considering more broadly experiences, the paper then asks whether there is an even greater argument for MaPP to be part of the overall toolkit in EMs. And if so, what MaPP could EMs best use going forward given their current situations?

We are not the first to study the use and effectiveness of MaPP. Most studies, however, take a more aggregate perspective, that is, they investigate the effects of MaPP at the overall economic or financial sector level-e.g., leverage or credit growth, the occurrence of a financial crisis, or at the level of subsector, such as real estate. We build on this work by investigating how MaPP may affect certain channels by which vulnerabilities and externalities can arise at the micro-economic level. Specifically, we explore the role of MaPP in limiting vulnerabilities in individual banks (and thereby overall banking systems). To also analyze the role of differences in country circumstances and conditions, we use a large sample of countries, including both ACs and EMs, and relatively open and closed capital

\footnotetext{
${ }^{1}$ While we use the distinction EM vs. ACs in most of the paper, in the empirical applications we also consider classifying countries as having relatively open vs. closed de jure capital accounts.
} 
account economies. And we differentiate by type of MaPP and by phase of the financial cycle-upswing or downswing.

We find that debt-to-income caps, loan-to-value ratios, and limits on foreign currency lending are effective in reducing several vulnerabilities during boom times, while countercyclical buffers (such as reserve requirements, profit distribution, and dynamic provisioning) help mitigate declines in bank leverage and asset growth in adverse times. Some MaPP aimed at mitigating the buildup of financial vulnerabilities, however, can work perversely during financial downturns as they make adjustments more difficult. We conclude that MaPP can be important elements of the policy toolkit aimed at overall systemic risk mitigation, especially for EMs exposed to international shocks. As they affect resource allocations, however, MaPP imply also some costs. Poorly designed or wrongly implemented, MaPP tools can be circumvented and imply further distortions. We therefore conclude that MaPP need to be properly chosen and calibrated carefully depending on country and financial system characteristics, including capital account openness, and adjusted as circumstances change, to provide all their benefits.

The paper itself is structured as follows. Motivated by the case of EMs, Section II discusses the conceptual rationale for MaPP in general, and discusses the various MaPP that can be used to deal with specific risks and shocks, depending on a country's structural features and macroeconomic and financial sector conditions. Section III looks at the empirical evidence on the actual use of MaPP and the effectiveness of different instruments in reducing banking system vulnerabilities. Section IV concludes, with reference to EMs' current situation, prospects and vulnerabilities, on whether and how MaPP can best be used.

\section{WHY MACRO-PRUDENTIAL REGULATIONS MAY BE NEEDED AND THE ACTUAL TOOLKIT}

The global financial crisis has highlighted that, even with macroeconomic stability, using a judicious mix of micro-prudential regulation, supervision and market discipline to address potential risks at the level of individual financial institutions, even if well-designed and implemented, does not suffice to ensure financial stability. When private and social costs and benefits of actions of individual financial institutions/agents diverge, measures which focus on individuals' actions and financial institutions' stability alone are not sufficient since they do not take account of externalities that can lead to a buildup of systemic risk. Furthermore, some policies, including micro-prudential regulations, while important to address public policy objectives at the individual institution's level, can lead to behavior that creates systemic risks. Neither are traditional macroeconomic management policies, notably monetary policy and fiscal policy, necessarily able or the most effective tools to contain (the buildup of) systemic risks, especially not for EMs (see further Ghosh, 2010 and Claessens and Ghosh, 2012). 
While the benefits of a broader approach was recognized some years ago by some, notably at the BIS, ${ }^{2}$ it is only now that policy makers and academics have started to acknowledge the need to use policy instruments that target the soundness of the financial system as a whole. In this context, MaPP are promising in principle, as academic research has also highlighted (for an early analytical review of the need for MaPP, see Brunnermeier, et. al. 2009; see also Hanson, Kayshap, and Stein, 2011, and De Nicolò et al, 2012).

Their use, however, requires a clear identification of the aspects of systemic risks that need to be addressed and their fundamental causes. Systemic risk can be cyclical — whereby financial institutions and markets overexpose themselves to risks in the upswing of the financial cycle and then become overly risk-averse in the downswing, rendering the entire financial system and economy vulnerable to booms and busts. Or it can be cross sectional-whereby individual (institutions') actions and problems can have spillover effects on the overall financial system. While both types of risks can arise from externalities and market failures, appropriate policy tools can vary between the two (Allen and Carletti (2011), Bank of England (2011), and Schoenmaker and Wierts (2011) provide similar classifications of sources of systemic risks and related policy measures).

Besides the distinction between addressing cyclical or cross-sectional types of systemic risk, it is also clear that MaPP need to be adapted to country characteristics and circumstances, and the efficacy of other tools - notably monetary, fiscal, micro-prudential and capital flow management policies - that can help address these risks (see IMF, 2011a for an organizing framework). Here research has made less progress as of yet in developing robust frameworks that can help choose the proper MaPP and calibrate their design (e.g., the level of a capital surcharge or loan-to-value limit). While recent work on capital account liberalization (IMF, 2011b; Ostry et al 2011) has helped clarify for what type of countries and circumstances, capital flow management (CFM) tools ("capital controls") can be envisioned, the equivalent analysis and framing are yet to happen in full for MaPP. The analyses in this paper contribute towards those efforts, including in how to identify the complementarity and substitute relationships between MaPP and CFM tools.

\footnotetext{
${ }^{2}$ In particular, the many works authored by Borio and White, including Borio and White (2003) and White (2006), highlighted the boom and bust patterns in financial markets and the need for broader tools. See Clement (2010) on the origins of the word "macroprudential", whose first recorded use at the BIS was in 1979.
} 


\section{A. Procyclicality}

The financial sector is inherently pro-cyclical, i.e., it amplifies the business cycle. ${ }^{3}$ The two way interactions between the financial sector and real sector "causing" this pro-cyclicality largely operate through changes in the values of assets and leverage. A positive shock (such as a productivity shock) increases the value of a bank's assets (e.g., loans, securities), and if the bank targets a desired leverage ratio, then the bank will increase its asset holdings in response to the increase in asset value. Faced with a common shock, if all financial institutions do the same, the increased demand for assets raises their prices, further fuelling the cycle and leading to a generalized expansion of credit.

In the process, banks' balance sheet structure can become more vulnerable to shocks (or a downturn in the economy) through a range of balance sheet mismatches and weaknesses. These include rising leverage ratios, maturity mismatches and, especially in the case of EMs and developing countries, foreign exchange (FX) mismatches. On the liability side, the ratio of non-core to core funding tends to rise. As banks seek to expand their balance sheets, they generally need to turn to non-core funding since more stable core (mainly deposits) liabilities tend to be more sluggish (see further Hahm, Shin, and Shin, 2011 for a model and empirical analysis on how the predictive value of this channel has for financial crises).

Once the financial system as a whole becomes more leveraged, it becomes vulnerable to shocks such as sudden withdrawals of funds, stops in capital inflows or changes in asset prices. Indeed even small shocks such as slight increases in borrower defaults or small declines in collateral values during a downturn can trigger system-wide problems. If equity buffers are insufficient to absorb losses, for example, banks may be forced to deleverage, in turn creating system-wide declines in the supply of external financing. Or a negative shock that shakes depositors' confidence can expose banks to the risk of runs, forcing to hoard liquidity or sell assets at depressed market prices to meet withdrawals, if the system-wide maturity transformation (lending long and borrowing short) or reliance on wholesale funds is high. Negative externalities related to fire-sales can then come into play as a generalized selloff of financial assets causes a decline in asset prices, which in turn further impairs the balance sheets of intermediaries amplifying the contractionary phase of the cycle.

\footnotetext{
${ }^{3}$ Procyclicality can arise from the behavior of financial intermediaries ("supply side") and from changes in borrowers' balance sheet and income statement. The latter amplification mechanisms, collectively known as "the financial accelerator," operate through the demand side of financial transactions. These models show how small shocks, real or financial, can be propagated and amplified across the real economy as they lead to changes in access to finance for corporations and households. Here the financial system is less a cause of, but more accommodates procyclicality. Obviously, there are many interactions between the demand and supply sides causes of procyclicality. See further Brunnermeier, Eisenbach and Sannikov (2012) for an analytical review of models of macro-financial linkages and Angelini et al (2009) for a general review of procyclicality in the financial sector.
} 
It is also possible that instead of-or in addition to-selling financial assets to regain liquidity and improve capital ratios, banks may reduce new credit extension, ration credit via higher margins/haircuts or by raising interest rates or other costs to borrowers (externalities related to credit crunches). Such deleveraging via reduced credit extension will have general effects as the economic showdown adversely affects borrowers by lowering output and prices. This raises the probability of default for all other borrowers and can set off a cycle of adverse effects on the real economy, again further amplify banking sector losses.

While positive (negative) exogenous shocks can be one trigger of a financial sector upturn (or downturn), that then gets amplified through the financial sector frictions and factors discussed above, there is also increasing recognition in the literature of the possible role of collective cognition. In the latter, the dynamics are endogenous to the financial development process itself, and get amplified by experience-based expectations. Thus faced with the new and unknown (say following a financial innovation and improving economy) market participants can be subject to waves of optimism and exuberance. At some point however, a significant dissonance initiates a mood swing fueled on the downturn by acute uncertainty aversion (de la Torre et al, 2011).

Although the financial sector thus naturally exhibits pro-cyclicality, several factors can amplify the build-up in and heighten its vulnerability-by accentuating pro-cyclical behavior, encouraging greater risk taking, or inducing correlated behavior (Figure 1). ${ }^{4}$

- Some aspects of micro prudential regulations intended to enhance stability at the level of the individual financial institutions, can actually increase the system's pro-cyclicality. This is the case, for instance, with the Basel capital requirements and other micro prudential regulations - designed to ease agency problems or frictions by providing some "skin in the game" (and buffers against unexpected shocks). Even under the essentially flat capital requirements of Basel I, bank capital regulation had the potential to be pro cyclical because bank profits may turn negative during recessions, impairing banks' lending capacity. Additionally, the Internal Ratings Based Approach (IRB) of Basel II makes capital requirements an increasing function of banks' estimates of their loans'

\footnotetext{
${ }^{4}$ These factors all result in externalities of one form or other. In the case of factors that exacerbate procyclicality, this externality takes place through the impact of individual financial institutions' actions on asset prices, which indirectly leads to correlated outcomes (expansion of balance sheets and balance sheet vulnerabilities). In the case of factors that give rise to strategic complementarity, the externality arises directly through correlated behavior.

${ }^{5}$ Agency frictions refer to frictions that limit the capacity of individuals to delegate and contract bilaterallyand hence hinder financial development - due to a) asymmetric information frictions (which lead to a misalignment of incentives between the principal (e.g. depositors) and the agent (e.g. the banker) because the agent who has more information on his actions can use his informational advantage to act in ways that are not in the interests of the principal; or b) contract enforcement costs.
} 
probability of default and loss given default, which are both likely to decrease (increase) during upturns (downturns). This thus creates pro-cyclicality, especially in downturns when the rules can substantially exacerbate the negative impact of recessions on banks' supply of credit and, thereby, on the economy as whole. Hence there are many concerns about the pro-cyclicality introduced by rules such as Basel II. ${ }^{6}$ Microprudential regulations may also encourage correlated asset choices across financial institutionssince these regulations assigned similar risk weights to certain asset classes, thereby favoring preferences of some asset classes over others and common choices.

- Some (non-prudential) policies or practices aimed at reducing agency and/or participation frictions ${ }^{7}$ can also increase risk taking and pro-cyclicality. For instance, remuneration contracts of managers commonly include a variable, performance-related component in order to better align the incentives between managers (agents) and shareholders (principals). However, the asymmetry of such schemes-whereby managers get paid highly if they make profits, but are not penalized for losses - can result in greater risk taking on their part. Similarly, limited liability, which applies to bank shareholders, as for any other corporate shareholder, and is designed to foster entrepreneurism (and in the case of the financial sector, participation in financial markets) can encourage greater risk taking. In particular, limited liability can encourage the use of Value-at-Risk models. Shareholders do not care about tail risks - for an equity holder protected by limited liability it does not matter whether the firm goes bust just marginally or whether it goes bust spectacularly (Shin, 2008). ${ }^{8}$ Since empirically, measured risk (e.g., volatility, which directly influences $\mathrm{VaR}$ ) is low during booms and high during busts, banks expand their balance sheets and increase leverage during upturns and contract their balance sheets and reduce leverage during downturns. This means that adopting VaR encourages procyclical behavior. Similarly, margins or haircuts that adjust over the cycle can also lead to greater procyclicality, especially in down cycles when margin/haircut spirals can occur. ${ }^{9}$

\footnotetext{
${ }^{6}$ However, for capital requirements to have contractionary effects some banks must find it difficult to respond to the accumulation of losses or higher capital requirements by issuing new equity and the borrowers of the constrained banks must be unable to switch to other sources of finance.

${ }^{7}$ Participation or collective frictions refer to frictions that constrain participation or financial inclusion broadly defined. Much of the gains from financial activity relate to a reduction in transactions costs, and increase in liquidity and risk diversification benefits. Hence limited participation can constrain financial development (de la Torre et al, 2011).

${ }^{8}$ Moreover, during the upswing, in a situation in which the best borrowers may already have access to the loans they want/or the list of sound projects are limited, banks' drive to expand their balance sheets may be associated with their moving down the quality ladder to lend to increasingly riskier borrowers/projects.

${ }^{9}$ The spiral arises because many institutions finance their asset positions with (short-term) borrowed money (repos) and have to put up margins in cash or are imposed a discount (haircut) on the assets they provide as collateral to assure the lender that the loan can be recovered in case the borrower defaults. These margins/haircuts increase in times of price declines - as lenders want more protection - and thereby lead to a general tightening of lending (margins and haircuts implicitly determine the maximum leverage a financial institution can adopt). The margin/haircut spiral then reinforces the capital adequacy and VAR channels in
}

(continued) 
- Some of these practices or policies generate strategic complementarities ${ }^{10}$ that lead to or actively encourage correlated behavior among financial institutions and markets and hence increase systemic vulnerability. For instance, correlated behavior can arise as a result of reputational concerns and the incentive structures for bank managers. When bank managers care about market perceptions of their ability, their credit policies are influenced by those of other banks (Rajan, 1994). Peer benchmarking can also give rise to correlated behavior because a bank reporting poor performance due to losses will be evaluated harshly unless many other banks suffer losses at the same time. Banks therefore have incentives to roll over bad loans to hide the loans until the buildup of bad loans forces them to coordinate to a strategy of loss recognition and credit contraction. The prospect of a government bailout in the event of financial distress can also lead banks to engage in correlated asset choice ex ante. As financial institutions try to mimic each other's strategy-knowing there is safety in numbers-there is an increase in the systemic vulnerabilities of the financial system (De Nicolò et al, 2012).

- Attempts at reducing agency, collective action or participation frictions that on one hand are associated with successful financial development can also, paradoxically, exacerbate systemic vulnerability. An example from de La Torre et al (2011) relates to the availability of public information. More public information can reduce the ability to appropriate rents from private information, which eases agency frictions. At the same time, though, it can encourage investors to free ride (leading to a collective action problem). Rather than investing in analysis and monitoring, and staying committed investors may invest short and rely on market liquidity to exit at the first sign of trouble.

\section{B. Risks from interconnectedness}

The cross-sectional dimension of systemic risk arises from the interconnectedness of financial institutions and markets. This interconnectedness can result in a specific shock to an institution or market at a point in time being amplified as it is propagated throughout the system (see Allen and Gale, 2007; Diamond and Rajan, 2001, Bebchuk and Goldstein, 2012). The shock may spread through the network of interconnected balance sheets of financial institutions when one systemically important institution is hit, or it can spread because of direct actual or anticipated common exposures of financial institutions to a particular asset class (e.g., commercial real estate, of foreign exchange risks) through financial markets and asset prices. Spillovers can also arise because feedback from the real economy.

making institutions reduce their leverage. See further Brunnermeier and Pedersen (2009), Adrian and Shin (2010), and Geanakoplos (2009).

${ }^{10}$ Strategic complementarity arises when the payoff to a certain strategy rises with the number of financial institutions adopting the same strategy (De Nicolò et al, 2012). 
Financial institutions can reduce but not entirely eliminate these externalities since the shape of interconnectedness in the financial system is beyond the individual bank's control. Externalities stemming from interconnectedness are particularly strong for systemically important financial institutions (SIFIs). Unlike smaller institutions, distressed SIFIs cannot be easily wound down, since they are large and complex, operate internationally, and play a role as backbones of the financial infrastructure. These institutions can then become too important to fail or too big to fail (TBTF), leading to government subsidies ex-ante - as they can attract financing at lower costs - and ex-post—as they get bailed out when they run into distress.

Cyclical and interconnectedness risks can interact to exacerbate vulnerabilities. Although links among financial institutions can help them to manage risk and distribute funds to where they can be deployed effectively, intra-financial system activity can also increase the tendency for lending to become excessive during the upswing of a business cycle as was discussed above. For instance, the dispersion of risks and the increased complexity in the financial system associated with securitization before the financial crisis reduced incentives to screen and monitor lending. This impairment in underwriting standards in turns exacerbated the extent of overborrowing in the real economy. Also funding chains between banks and other financial intermediaries can mean that system wide maturity transformation may be high, even though maturity transformation at any individual level may appear small.

Linkages within financial systems can also tend to exhibit pro-cyclicality and contribute to time-varying risk in its own right by increasing the potential for contagion during exuberant periods, and increased risk aversion during times of financial turmoil. In particular, for a given level of lending to the real economy, a system that has longer, larger or more opaque chains of intra-financial system claims is more prone to amplifying shocks through counterparty risk. Excessive intra-financial system activity also poses liquidity risks. Due to greater sensitivity to individual firm characteristics and market wide sentiment, wholesale funding may be particularly flighty and shocks to one or more institutions can propagate withdrawals of funding in interbank and other wholesale markets during times of stress.

Most of these risks appear in all types of countries, but with some variation. For ACs, besides domestic financial cycles often related to real estate booms and busts, interconnections among large SIFIs and through financial markets are important drivers of systemic risks. For EMs, with still less developed financial systems with smaller, less systemic banks and fewer interconnections, cyclical risks often related to global financial cycles and capital flows (especially in the form of bank flows) are important drivers of overall risk (see also Shin, 2012). For further differences between EMs and ACs in terms of the typical behavior of business and financial cycles, we refer to Claessens, Kose and Terrones (2011a and 2011b). 


\section{The actual macro-prudential toolkit}

To mitigate these causes of systemic risk, a number of MaPP-instruments have been proposed and some have been used, even before the global financial crisis. ${ }^{11}$ Table 1 categorizes these measures in a 3-by-5 matrix (for other classifications of MaPP, see Bank of England, 2011, and IMF 2011a). In reviewing different types of MaPP, most analysts find it useful to distinguish the measures that aim to reduce those externalities that contribute to adverse financial sector dynamics in three groups (along the vertical axis), namely: a) measures that aim to dampen the expansionary phase of the cycle; b) measures that aim to reinforce the resilience of the financial sector to adverse part of such cycles; and c) those that aim to ensure the internalization of interconnectedness-related spillovers. The first two groups are aimed at reducing the occurrence and consequences of cyclical financial risks, while the third is aimed at the risks arising from interconnectedness.

Observers also tend to classify MaPP by intended target and method. Table 1 does this (along the horizontal axis) in five groupings, namely: a) capital and provisioning requirements; b) other quantitative restrictions on financial institutions' balance sheets; c) quantitative restrictions on borrowers, instruments or activities; d) taxation/levies on activities or balance sheet composition; and e) other, more institutional-oriented measures, such as accounting changes, changes to compensation, etc.

Specific measures under each of the $15(3 * 5)$ combinations include those correcting for fundamental factors that can give rise to externalities and market failures and those that compensate for policy factors that can contribute to adverse financial dynamics (such as the pro-cyclicality of micro-prudential capital requirements). The measures in the first four columns are meant to be time-, institution-, and state-varying, while the ones in the fifth column are meant to be more structural. And some measures fall into more than one of the combinations. Note that many of the measures are traditional micro-prudential tools that, by making them time-, institution-, or state-varying, are used to achieve macro-prudential objectives such as dampen the amplitude of the cycle. We discuss the more important ones.

Capital and provisioning requirements, in the first column, can have an impact on reducing the amplitude of the upswing of the cycle (first row), but are primarily thought of for building more resilience in the financial sector (second row). Under Basel III, for example, a countercyclical capital buffer ranging between $0-2.5$ percent of risk weighted capital is to be introduced on top of the capital conservation buffer, when aggregate credit and other

\footnotetext{
${ }^{11}$ Note that many of these instruments can also serve some other policy objectives, including, besides microprudential objectives, consumer protection and competition policy.
} 
indicators are judged to signal a buildup of systemic risk. ${ }^{12}$ General dynamic provisioning is also a countercyclical tool that builds up a cushion against expected losses in boom times (first row) that can be reversed during the downswing (second row) ${ }^{13}$ Both countercyclical requirements could help dampen the effects of externalities associated with strategic complementarities in the upswing as well as with externalities related to fire sales and credit contraction in the downswing. A few countries have already used some variant of these measures, allowing for analyses of its effectiveness (see Jimenez, Ongena, Peydro and Suarina, 2012, for the case of Spain). A capital surcharge on systemically important (TBTF) financial institutions (third row), also proposed under Basel III, is geared towards mitigating the externalities associated with financial institutions' interconnectedness.

Restrictions on banks' balance sheets, in the second column, are often considered for microprudential purposes. They can also be used to achieve macro-prudential objectives such as dampen the amplitude of the cycle (first and second rows). Measures range from (time varying) restrictions on balance sheet mismatches, such as on foreign exchange mismatches, and maturity mismatches. Reserve requirements (RR), that require banking institutions to hold a fraction of their deposits/liabilities as liquid reserves normally held at the Central Bank in the form of cash or other forms such as government securities, have in the past been used as a liquidity and credit policy tool, i.e., as a monetary policy tool. They can, however, also be used as a macroprudential tool to affect asset composition and dampen procyclicality ${ }^{14}$ Especially in EMs and developing countries do reserve requirements appear to be used that way. Federico Vegh and Vuletin (2012), for example, find in a sample of 52 countries, that 74 percent of developing countries have used reserve requirements countercyclically. RRs can be applied on liabilities and on assets (the latter would entail holding reserves against different asset classes, with the regulator setting adjustable reserve requirements on the basis of its concern with each asset class, Palley (2004)).

Given the potential risks arising from a liquidity shortage during the contractionary phase, as evidenced during the global financial crisis, Basel III discussion also includes a proposed set

\footnotetext{
${ }^{12}$ According to the original guidance document (BCBS 2010), the authorities' intentions to raise the level of the capital buffer would be preannounced by up to one year, but a decision to decrease the buffer would take place immediately.

${ }^{13}$ Most of the dynamic provisioning (DP) measures are a variation on the following rule: DP = through-thecycle Loss Ratio x Flow of New Loans minus flow of specific provisions (where specific provisions correspond to realized losses). Thus the formula implies that during boom times dynamic provisions are positive and contribute to the increase in loss provisions as realized losses are below the-through-the cycle loss ratio. The requirement for extra buildup of loan-loss provisioning could act as a brake during boom times. The reverse is true during downswings, with the drawdown serving as an additional cushion.

${ }^{14}$ When applied to deposits, regulations usually specify the level of the requirement according to deposit type (e.g., demand or time) and its currency denomination (domestic or foreign). Regulations also set a holding period relative to the reserve statement period for which the RR is computed and whether they are remunerated or non-remunerated. When they apply to new deposits only they are referred to as marginal RRs. In addition RRs can apply to domestic or foreign non-deposit liabilities of banks' balance sheets.
} 
of liquidity requirements (second row): the liquidity coverage ratio (LCR) and the net stable funding ratio (NSFR). ${ }^{15}$ To reduce buildup of systemic risks and the externalities that can arise during the contractionary phase, restrictions on balance sheets can also include imposing requirements in a countercyclical manner on non-core to core funding, leverage or other ratios.

Additional measures aim at enhancing the resilience of banking system to reduce risks of spillovers (third row). Here measures can be micro-prudential in nature as well, like restrictions on financial institutions' bilateral exposures or other balance sheets limits, but be designed and used with the macro-prudential objectives of reducing interconnectedness.

Measures related to borrowers (third column) in the expansionary phase of the cycle (first row) are typically designed to limit the leverage of borrowers to manage financial institutions' credit risk and include (time varying) caps on loan to value (LTV) ratios (which can also be applied differentially to loans of different characteristics (mortgages, central versus peripheral locations, etc.) and (time varying) caps on debt to income (DTI) ratios. And caps on credit growth (CG) directly address asset growth and the potential risks during the upswing of the financial cycle. These measures can act as a brake on banks' asset growth, but also help to reduce leverage and the impact of declines in asset prices and economic prospects during downturns (second row). Structural measures limiting banks' activities (third row), such as the Volcker rule in the US and the Vickers rule in the UK, can limit the risks of spillovers due to interconnections.

As proposed among others by Shin (2010) and discussed by IMF (2010), a tax or levy (fourth column) applied to some balance sheets concept can serve to mitigate the externalities that lead to excessive asset growth during the upswing, for example, by limiting risky funding (first and second row). For bank and nonbank financial institutions engaged in market-based activities, macroprudential regulations can take the form of pro-cyclical margin requirements (see, e.g., Geanakoplos, 2009; Gorton, 2009; Gorton and Metrick, 2010). Requiring throughthe-cycle margins or haircuts can help mitigate the externalities arising during the

\footnotetext{
${ }^{15}$ The LCR goal is to ensure that banks have liquidity to survive one month of stressed funding conditions. Therefore the LCR identifies the amount of unencumbered (i.e., not pledged and not held as a hedge for any other exposure) high quality liquid assets that can be employed to offset expected cash outflows over a 30 day horizon. The net stable funding ratio (NSFR) is a complement to the LCR with a goal of addressing longer term structural maturity liquidity mismatches in banks' balance sheets. It sets a minimum acceptable amount of stable funding based on liquidity characteristics of a bank's assets over one year horizon. The NSFR is defined as the ratio between available stable funding and required stable funding. Stable funding includes those types and amounts of equity and liability financing expected to be reliable source of funding over one year horizon under stress scenarios. Stable funding is defined as total amount of capital; preferred stock with maturity greater than one year; secured and unsecured borrowing and liabilities (including deposits with effective maturities of one year or greater; proportion of stable wholesale funding, non maturity deposits and/or term deposits of less than one year expected to stay with the institution for an extended period of idiosyncratic stress.
} 
expansionary and contractionary phase as it would mean margins remain higher (lower) during up (down-) swings. Also levies on non-core liabilities can help reduce the probability that financial institutions would run into aggregate funding problems in the first instance. And similar to a capital surcharge, a tax can be levied on systemically important (TBTF) financial institutions to encourage them to reduce their externalities (third row).

Finally, a wide set of institutional infrastructure changes can serve a macro-prudential role (fifth column) as either they limit the frictions or deeper distortions that give rise to financial cycles in the first place (first and second) row or help reduce with the spillovers by building stronger protections (third row). For further discussion of these more institutional-oriented measures, we refer to Andritzky et. al. (2009).

\section{WHAT MAPP HAVE COUNTRIES USED SO FAR AND HOW EFFECTIVE HAVE THEY BEEN?}

The previous two sections discussed the various analytical reasons for MaPP and the specific tools countries can use in principle. The preferred use will vary depending on the specific country's exposure to shocks and risks, and its specific structural, institutional and financial market characteristics that tend to amplify financial and real sector cycles. It could also vary depending on the availability and effectiveness of all the elements of the broader policy toolkit to mitigate financial cycles, including besides MaPP instruments, fiscal, monetary, and micro-prudential policies. Institutional environment constraints (e.g., lack of data, knowhow), political economy, and other factors may lead countries to adopt MaPP in ways different from what is preferable. And, a major issue is that little is known on the actual effectiveness of various MaPP, meaning usage often has proceeded on an experimental basis.

This section first reviews the actual use of MaPP for a large sample of countries. It next reviews the existing literature on the effectiveness of MaPP. It then evaluates for these countries using panel regressions the effectiveness of various tools and approaches to reduce financial vulnerabilities in the banking system.

\section{A. Use of MaPP}

Data on actual use of MaPP in recent years have been collected through a survey of country authorities for a sample of some 48 countries, both ACs and EMs (see further Lim et al, 2011 for the exact coverage and definitions) as well as from an internal IMF survey of country desk economists. A dummy variable for each instrument takes the value of 1 for countries and years in which that instrument is used or zero otherwise. The eight specific instruments (Table 2) are: caps on loan-to-value (LTV) and debt-to-income (DTI), limits on credit growth (CG), limits on foreign lending (FC), reserve requirements (RR), dynamic provisioning (DP), counter-cyclical requirements (CTC), limits on profit redistribution (PRD), and a residual 
category (Other). Only for some of the MaPP do we also know the level: caps on LTV and DTI ratios, which vary from 0 to 1 and 0 to 0.5 respectively. To be consistent with the other MaPP, however, we just use dummies to indicate the use of caps on LTV and DTI ratios.

Of these, a total of 30 countries, of which 6 ACs and 24 EMs, have implemented at least one of these MaPP instruments during the period 2000-2010, with EMs the most frequent users (columns 1 vs. 2). The only ACs that have used MaPP over this period are France and Spain in case of LTV, Hong Kong in case of DTI, Singapore for credit growth limits, Austria for foreign exchange limits, Spain for dynamic provisioning, and Norway for Other MaPP, including countercyclical tools (see further Table 3). All other usage of MaPP is by EMs. This pattern is consistent with the greater needs in EMs, both for being exposed to more external shocks and for having more "imperfect" financial markets, both banking systems and capital markets, and more frequent necessity to tackle market failures. ${ }^{16}$

We also differentiate countries between open and closed capital account on the basis of the country having a Chinn-Ito (2008) index of financial openness in 2005 above (32 countries) or below (15 countries) the median global index. ${ }^{17}$ The capital account dimension is analytically useful distinction as it indicates what risks are (more) important and has clear policy implications on how international financial integration may need to be managed. While many of the MaPP tools have been used by EMs, some have relatively open capital accounts, but others have relatively closed capital accounts. In turns out that MaPP are more frequently used in closed capital account countries, reflecting perhaps their generally less liberalized financial systems (see Table 2). Specifically, all of the 15 closed capital account countries have implemented at least one of these MaPP instruments over the 2000-2010 period, compared to only 14 of the 32 open capital account countries.

There is a strong trend of increased usage of MaPP since the 1990s (Figure 2), which confirms the growing recognition of the value of MaPP throughout time, with EMs in particular using MaPP more over time, both before and after the recent financial crisis. On average, MaPP were four times more likely to be used by EMs than by ACs in the period right before the crisis (with this ratio declining to 3.3 in the period following the crisis as

\footnotetext{
${ }^{16}$ There are also many possible interactions between MaPP and capital flow management (CFM) tools. This is in part as some MaPP operate in such a way that they can be considered a CFM tool (e.g., limitations on foreign currency exposures for banks that end up affecting mostly non-residents, see Ostry et al 2011). In addition, MaPP can also affect the need for CFM tools. For example, by reducing the demand for loans, LTV caps can reduce the demand of banks for (whole-sale) funding, some of which may be in foreign exchange.

Consequently, a LTV cap can indirectly reduce the need for CFM tools to be used.

${ }^{17}$ Note that we use the global median Chinn-Ito index, that is, the median within the whole Chinn-Ito dataset, not the median within this sample, which is why we have more open than closed countries. We do not have Chinn-Ito data for Serbia, which is why there are 47 instead of 48 countries when using capital account groups.
} 
ACs started to introduce MaPP). Differentiating countries between open and closed capital account leads to less sharp, but qualitatively similar differences in the actual use of MaPP. The most often used MaPP (column 8 in Table 2) in this sample of countries is dynamic loan-loss provisioning (DP): in about $23 \%$ of the country-year combinations when a MaPP was used, it was DP. Next are debt-to-income (DTI) and foreign currency (FC) lending limits, used about $18 \%$ of the cases each, followed by loan-to-values (LTC) caps, credit growth $(\mathrm{CG})$ caps and reserve requirements (RR).

In terms of specific MaPP, there are differences between EMs and ACs (Figure 3, upper panel; see also columns 1 and 2 of Table 2, which report the numbers of countries, and columns 9 and 10, which report the percentage by country-year observations). The higher exposure to systemic banking system risks, in particular through capital flow volatility, may explain the more frequent use of MaPP by EMs. Because EMs tend to be more concerned with large and volatile capital inflows and with systemic liquidity risk, they especially tend to favor capital flow- and liquidity-related related policies (limits on net open positions, reserve requirements, and caps on FX lending). But they also more often use dynamic provisioning and limits on profit distributions. On the other hand, ACs are relatively more concerned with risks generated by strong credit growth and asset price inflation, or risks arising from excessive leverage and the consequent de-leveraging, and tend to prefer relatively more credit-related measures, such as LTVs (67\% of all country-year observations).

MaPP can also be expected to be used differently in open vs. closed capital account countries in part as the source of systemic risks may vary. There are indeed differences in the relative use of MaPP (Figure 3, lower panel; see also columns 3 and 4 of Table 2). While LTV caps and foreign currency limits, for example, have been used almost equally in both open and closed economies, reserve requirements are only used in relatively closed capital account countries. Otherwise, the differences in actual use of MaPP between open and closed economies are not as stark as those between EMs and ACs. This likely reflects that while on one hand there are differences in risk exposures, on the other hand there are differences in financial systems, in part related to the degree of financial liberalization, which make some MaPP less attractive to use.

\section{B. Effectiveness of MaPP: existing studies}

Some existing papers have analyzed the effects of MaPP on various measures of financial vulnerability and stability. For example, Lim et al. (2011) explore the role of MaPP on affecting credit and leverage growth, while Crowe et al. (2011) explore the effects of MaPP like LTVs on real estate booms and busts. These studies have documented some evidence of some MaPP being effective. Lim et. al. (2011) using cross-country regressions, find that MaPP to be effective in reducing the procyclicality of credit and leverage. Specifically, they 
find that tools, such as LTV and DTI caps, ceilings on credit growth, reserve requirements, and dynamic provisioning rules, can mitigate the "procyclicality" of credit.

Crowe et al. (2011) find that MaPP such as maximum LTV linked to the real estate cycle appear to have the best chance to curb a real estate boom. They argue that the narrower focus of such tools reduces their costs. And, in the case of measures aimed at strengthening the banking system (such as dynamic provisioning), even when they fail to stop a boom, they argue that such tools may still help to cope with the bust. Vandenbussche, Vogel, and Detragiache (2012) investigate for countries in Central, Eastern and Southeastern Europe whether prudential policy measures had an impact on housing price inflation. Their evidence suggests that measures like capital ratio requirements and non-standard liquidity measures (marginal reserve requirements on foreign funding, marginal reserve requirements linked to credit growth) helped slow down housing price inflation.

Dell'Ariccia et al (2012) conduct an empirical investigation of the use of MaPP in mitigating general credit booms and busts. Their results suggest that MaPP can reduce the incidence of credit booms and decrease the probability that booms end up badly. ${ }^{18}$ Consistent with the focus of MaPP on financial vulnerabilities, they find a reduction in the probability of a bad boom, primarily for booms that end up in a financial crisis, although the effect on the probability of economic underperformance is not very different. They conclude that MaPP can reduce the risk of a bust while simultaneously reducing the vulnerability of the rest of the economy to troubles in the financial system.

Besides these cross-country studies, there are also some case studies, often focused on specific risks or market segments. Jiménez et al (2012), for example, find for the case of Spain that countercyclical macro-prudential policies, such as dynamic provisioning, are useful in taming credit supply cycles. More importantly, they find that during bad times, dynamic provisioning helps smooth the downturn, upholding firm credit availability and performance during recessions. Igan and Kang (2012) find evidence of effects of LTV and DTI limits on mortgage credit growth in Korea.

\section{Data used for new analysis}

We next empirically analyze the effectiveness of various MaPP countries have used. We perform our analysis using the panel data set of MaPP used described above and relate these to banking system vulnerabilities measures, in particular changes in three banking variables: leverage growth, asset growth, and noncore-to-core liabilities growth. Our main data source for the annual bank balance sheet data is the Bankscope database, which standardizes balance

\footnotetext{
${ }^{18}$ When estimating regressions using the subcomponents of their macroprudential index, they find that credit and interest controls and open foreign exchange position limits enter significantly in most regressions, although their significance is sensitive to the specific combination of variables included.
} 
sheets statements to adjust for various accounting and auditing conventions so that they are (reasonably) comparable. The sample of banks is chosen so that for each country we cover the top 100 (or less if fewer exist) banks based on total assets (we do not include all banks in the database so as to avoid the sample being dominated by ACs where there are many banks, such as the US, Germany and Japan).

All financial statement numbers are annual data and in US dollars. Leverage growth is calculated as the logarithmic growth of a bank's total assets to total equity ratio. Asset growth is calculated as the logarithmic growth of a bank's total assets. And non-core to core liabilities growth is calculated as the logarithmic growth of noncore liabilities to core liabilities. To remove the effect of outliers, we winsorize all bank balance sheet ratios at the five percent level in both tails of the distribution. We end up with approximately 2800 banks in 48 countries over the period 2000-2010, of which approximately 1200 banks in 24 EMs and 1600 banks in 24 ACs. Out of these 48 countries, 30 have adopted a macro-prudential policy tool at any time during 2000-2010.

Table 4A provides summary statistics of the dependent and independent variables used. It shows the large variation in these measures among individual banks, even with the removal of outliers. The included banks for example vary greatly in size, from $\$ 1.3$ million to $\$ 3$ billion. Also, asset growth figures vary greatly among banks, from $-61 \%$ to $114 \%$ per year. Some banks do not rely at all on non-core liabilities, whereas for some banks, non-core liabilities can reach up to 5 times core liabilities. And the growth in the reliance on non-core liabilities varies greatly as well, from $-98 \%$ to $113 \%$ year-on-year.

Differences across groups of countries are large as well, with some to reflect the intensity of the financial cycles countries have experienced. Table 4B makes clear that the boom and bust parts of the cycles are different in EMs compared to ACs and in open versus closed capital account countries. For example, the typical expansionary phase is stronger in EMs than in ACs, with much larger leverage, asset and non-core to core liabilities growth than in ACs, while the typical contractionary phase is deeper in EMs than in ACs. This translates into more intense booms and busts in EMs, with deeper and more violent downturns, but also stronger and faster recoveries. Closed capital account economies differ from open capital account economies in similar ways, with closed countries having greater increases and decreases in financial variables. This could suggest that capital account restrictions are adopted by those countries more exposed to risks, including to global shocks. Or it could be that more closed countries have less developed financial systems, which are more prone to transmit external shocks.

Important, there also seem to be some differences between those countries that have adopted MaPP and those that have not, in that the median increase/decrease in financial risk variables 
seems to be higher for those that have adopted some MaPP. This points to the fact that those countries experiencing more dramatic swings in bank leverage, assets and non-core to core liabilities growth are also those which have a greater need or willingness to adopt MaPPs. These aspects make it important to control for the endogeneity of MaPP.

Additional annual country-level macroeconomic controls are obtained from the IMF's International Financial Statistics (IFS) database and other sources. The variables collected are meant to proxy, among others, for whether the country is in an expansionary or contractionary phase of the business cycle, and whether other macroeconomic policies were used that may be complementary to MaPP aimed at limiting the pro-cyclicality of leverage, asset and non-core to core liabilities growth.

Specifically, we include the real GDP growth rate-to proxy for the state of the business cycle, and the change in the policy interest rate-to control for changes in the monetary policy stance, both of which can be expected to affect the financial cycle. We also include the change in the nominal effective exchange rate - to control for the effects of exchange rate changes on both the measurement of the banks' balance sheets in dollars and the fact that increased capital in- or outflows can be associated with both the domestic financial cycle and changes in the exchange rate.

To control for the degree of exchange rate flexibility, we include a variable which varies from 0 for a completely fixed exchange rate (i.e., a de facto peg or membership of a currency zone), to 6 being a free-float regime. The exchange rate arrangement can matter in two ways for banking system vulnerabilities. A more fixed exchange rate arrangement can limit monetary policy as an instrument to mitigate the business and financial cycles and it may thus lead to more booms (and busts). It may also mean to some moral hazard as the fixed rate implies a more explicit form of insurance of the banking system against risk-taking. At the same time, the exchange rate arrangement can also affect our measures of banking system vulnerabilities since these are recorded in US dollars. This means that, depending on the local vs. foreign currency composition of banks' balance sheets, fluctuations in the dollar- local currency rate can get reflected in our measures if the exchange rate is (more) flexible.

Raw statistics for these country variables, including the use of MaPP, are presented in Table 4A. In terms of GDP growth, the mean real economic growth in emerging markets tends to outperform growth in advanced economies. In terms of changes in the exchange rate, the growth of the nominal effective exchange rate is lower in EMs compared to ACs, while the growth of the real effective exchange rate is larger in EMs compared to ACs. In terms of the central bank policy rate, EMs have higher rates than ACs do over the period 2000-2010, and have moderated their rates at a slower pace than ACs did since 2000. 


\section{Empirical model}

The empirical model we use to investigate the effectiveness of instruments is Generalized Method of Moments (GMM) panel regressions. We use this to assess the effects of the seven macro-prudential policy instruments on our three risk variables, comparing the use of each instrument with an alternate scenario where no instrument is used. The GMM model is advantageous because it addresses any endogeneity problems (e.g., countries that use a macro-prudential instrument may be the ones that need it the most at a given point in time). The GMM system estimator satisfies the orthogonality hypothesis between the lagged endogenous variables. The lagged variables are used as instruments for the dependent variable and are weighted such as to minimize the asymptotic variance of the estimator.

We define the model as follows:

$$
\begin{aligned}
\Delta Y_{i, c, t} & =\alpha+\lambda * \Delta Y_{i, c, t-1}+\beta * M a P P_{j, c, t}+\varphi^{*} M^{*} P_{j, c, t} * \Delta Y_{i, c, t-1}+\theta^{*} X_{c, t-1}+ \\
& +\mu^{*} Z_{i, c, t-1}+\mathcal{E}_{i, c, t}{ }_{M a P P}
\end{aligned}
$$

For each bank $i$ in country $c$ in year $t, \mathrm{Y}_{\mathrm{i}, \mathrm{c}, \mathrm{t}}$ is a vector that represents the change in bank risk variable. In terms of right-hand side variables, all regressions include a lagged dependent variable, to allow for natural convergence in the respective financial variable. To control for macroeconomic developments and fiscal and monetary policies, we include $X_{\mathrm{c}, \mathrm{t}-1}$, a vector consisting of our lagged country-level macroeconomic variables. Specifically, we include the country's annual GDP growth, the change in its effective nominal exchange rate and policy interest rate, and the flexibility of its exchange rate arrangement. We also control for individual bank conditions, by including vector $Z_{\mathrm{i}, \mathrm{t}-1}$ which consists of a bank's capital adequacy and liquidity positions in the previous year. In addition, in all regressions, we include a time trend to control for any time-varying effects, such as change in global economic or financial conditions, and include individual country-fixed effects to control for any omitted time-invariant country effects.

In terms of the policy variables of interest, the matrix $\mathrm{MaPP}_{\text {,c,t }}$ is a set of dummy variables that take the value of 1 during years in which a macro-prudential instrument $j$ is used in country $c$ and zero otherwise (this way we allow for a macro-prudential instrument $j$ to be removed if circumstances call for it). Only loan-to-value (LTV) and debt-to-income (DTI) caps are included as levels, while the rest of five macro-prudential policies are included as dummies. Countries that never use any instrument form part of observations, with values of zero for all instruments. As such, we also control for the normal behavior of our risk variables in the absence of MaPP. We run the regressions first with each of the seven MaPP individually (but always including Other MaPP). Next we include all MaPP in one single regression specification. This way we can investigate if there are any complementarities 
between the various MaPP (for example, it could be that using the LTV is more effective when at the same time the country also has limits on DTI).

We also investigate if the effect of specific MaPP varies by the intensity of the financial cycle. We do this by including $\mathrm{MaPP}_{\mathrm{j}, \mathrm{c}, \mathrm{t}} * \Delta \mathrm{Y}_{\mathrm{i}, \mathrm{c}, \mathrm{t}-1}$, which is the interaction between the specific macroprudential instrument and the lag of the bank risk variable, calculated as a matrix to capture pro-cyclicality. Statistically significant coefficients for these interactions variables would indicate that the macro-prudential instrument(-s) are more effective when the intensity of the ongoing financial boom (or bust) is higher. This could be expected when for example the macro-prudential authority tightens a tool in response to a high growth.

We furthermore investigate whether there are differences between the effects of certain MaPP during different phases of financial cycles. We can expect some MaPP to be more effective in term of mitigating the boom part of the financial cycle. As noted in section II, LTV, DTI, CG, and FC are typically more seen to mitigate externalities arising in the upswing of the financial cycle. And MaPP such as RR, DP, and PRD are more seen as building buffers that can be draw-down in the adverse part of the cycle, and thereby mitigate any bust. We therefore create a dummy which we call MaPP-Expansions, that is 1 if any one (or more) of the following MaPP is used: LTV, DTI, CG, and FC. And we create a dummy which we call MaPP-Contractions, that is 1 if any one (or more) of the following is used: $\mathrm{RR}$, DP, and PRD. In a separate set of regressions, differentiating upswings from downswings, we then include these additional two dummies, both independent and interacted with each of the three lagged financial variables. The interactions allow us to answer the question whether either set of tools are particularly effective in mitigating a large boom or reducing the adverse impacts of a large correction. Lastly, we also explore differences between countries by investigating if results vary between ACs and EMs and between closed and open capital account countries.

\section{E. Regression results}

Table 5 reports the first results of the GMM procedure for the three risk variables. The full sample consists of 2800 banks in 48 countries, but because some of the country variables are not available for all countries, the regressions use a smaller sample of some 1300 banks. Columns (1), (5) and (9) present the results of regressing the risk variables only on lagged independent variables and control variables, including bank-specific and macroeconomic developments and policies. The coefficients on the lagged dependent variables are consistently negative, indicating that there are some natural mitigating forces leading to the risks not to increase unbounded. For example, when leverage growth is high this period, it can be expected to increase less next period since there are limits on banks' balance sheets expansions, like capital adequacy requirements, and market discipline may act as a mitigating force on individual financial institutions. The coefficients on the bank-specific variables are 
as expected. Stronger banks with better capital positions tend to have higher growth in all three variables. The effects of liquidity are less clear a priori, in part since liquidity can be adjusted faster than capital positions. Only the coefficient on liquidity for the non-core growth is statistically significant negative. This likely reflects that banks with better liquidity are less in need to grow their non-core funding.

In term of country variables, the coefficient on lagged real GDP growth is significant and with the expected positive sign in all three specifications. In terms of quantitative effects, for every 1 percentage point increase in real GDP growth, bank leverage growth increases by 0.25 percentage points, total assets growth by 0.21 percentage points, and non-core to core liabilities growth by 0.28 percentage points. The results thus show that the state of the real business cycle, proxied here by GDP growth, is strongly associated with increases in bank risk. Monetary policy seems to play a role in curbing banks' risks, with results consistently negative across all three measures. A 1 percentage points increase in the local interest rate (a tightening of the monetary policy stance) decreases leverage growth by about 0.01 percentage points, asset growth by about 0.03 percentage points and the non-core to core liabilities growth by about 0.11 percentage points. Since average leverage, asset and non-core to core liabilities growth are about $0.3,13.4$ and 0.2 percentage points respectively, these are economic significant effects for the non-core to core liabilities growth, but less so for leverage and asset growth.

The result for non-core to core liabilities is consistent with Adrian and Shin (2000), who also find relatively large effects of changes in monetary policy on bank funding structures. And the limited effects on asset growth is consistent with the general literature that finds that large increases in monetary policy are needed to stop credit boom and prick asset prices bubbles. Crowe et al (2011), for example, find for real estate booms that a 100 basis point hike in the policy rate would reduce house price appreciation by only 1 percentage point, compared to a historical average of 5 percent increase per year, but it would also lead to a decline in GDP growth of some 0.3 percentage points.

The results also show that the type of exchange rate regime is an important determinant of booms in leverage, asset and non-core to core liabilities. Such booms seem to occur more frequently in countries with floating exchange rate regimes. This may be due to the fact that countries with floating exchange rate regimes have less capital controls or subject to more frequent episodes of capital inflows. It could also be that the exchange rate regime affects our measurement of banking system vulnerabilities. The change in the nominal effective exchange rate always has a positive sign for asset and non-core to core liabilities growth, but a negative sign for leverage growth. Our interpretation is that when currencies appreciate (depreciate) due to capital inflows (outflows), there is a concurrent asset and non-core to core liabilities growth, maybe as capital flows go through the banking system and come in the 
form of wholesale funds (see Bruno and Shin, 2012, and Hahm, Shin, and Shin, 2011, for evidence). When there is an exchange rate appreciation, possibly due to large capital inflows, however, equity and other asset prices might concurrently increase, causing overall debt obligations to relatively decline (since foreign debt is now less when measured in local currency). Thus, an appreciation in the exchange rate could lead a bank's measured leverage (debt to equity) ratio to grow less overall.

Columns (2), (6), and (10) of Table 5 present the results of the effectiveness of specific MaPP instruments in reducing bank risk in levels, while the effectiveness of MaPP by intensity of the change in risk is investigated in columns (3), (7) and (11). We only show the coefficients for the macro-prudential policy instruments, but all regressions control for the same independent variables as in equations (1), (5) and (9), i.e., for macro-economic and financial country characteristics and bank-level characteristics. Regressions set (2), (6), and (10) and (3), (7) and (11) are run with one MaPP at a time, so that each row of results refer to that MaPP only, while columns (4), (8) and (12) present the results when simultaneously including all MaPPs. All these regressions continue to control for the countries' economic performance, the monetary policy stance, exchange rate change, and exchange rate regime, and key banks' characteristics.

Results from these additional regressions confirm that many of the MaPP help in controlling banking system vulnerabilities, as many coefficients are significantly negative. Many results also hold when including all MaPP at the same time, suggesting that there are some complementary relationships between the various MaPP.

Specific results can be summarized as follows:

- Measures aimed at borrowers: For all three bank risk variables, the coefficients on both LTV and DTI are statistically significant and with the expected sign for all regressions, in levels and mostly when interacting with the intensity of the cycle. This implies that the two instruments reduce bank leverage growth, asset booms, and non-core to core liabilities growth and are especially effective when there is more pro-cyclicality in these variables. The regression results suggest that LTV caps reduce leverage growth by some 0.9 percentage points, asset growth by 2.2 percentage points and non-core to core liabilities growth by 15.8 percentage points. Limits on DTI generally have a much greater impact on bank risk ratios. When introduced, DTI limits reduce leverage growth by 5.5 percentage points, asset growth by 3.9 percentage points, and non-core to core liabilities increases by 3.9 percentage points. These two MaPP are also effective in curbing the severity of the leverage and non-core to core liabilities cycles as the coefficients on the LTV and DTI interacted with the lagged dependent variables are negative and significant across the specifications (except when all MaPP are entered at the same time). 
- Measures aimed at financial institutions (addressing asset side): Many of the instruments aimed at financial institutions (limits on credit growth-CG, and foreign currency lending limits-FC) are statistically significant both in levels and when interacting with the intensity of the cycle. The introduction of limits on credit growth decreases asset growth by 0.6 percentage points, while limits on foreign lending decreases leverage growth by 1.8 percentage points and asset growth by 1.0 percentage points. They are both also more effective when the cycle is more intense, with limits on credit growth decreasing the growth of all bank risk measures, while limits on foreign lending decrease leverage growth and non-core to core liabilities growth when the cycle is more intense.

- Measures aimed at financial institutions (addressing liabilities side): Reserve requirements (RR) significantly reduce both leverage and asset growth both in levels and more so when the intensity of these cycles is greater. Reserve requirements also reduce non-core to core liabilities growth, but only in the regression when all MaPP are entered simultaneously.

- Measures addressing bank buffers: Dynamic provisioning (DP) and restrictions on profit distribution (PRD) do not appear to be very robust instruments. DP is significant in reducing only bank asset growth both in levels and during the cycle, with no effect on bank leverage or non-core to core leverage growth, and only some dampening effects on leverage and asset growth when entered jointly in a regression with other the MaPP instruments. Restrictions on profit redistribution do not seem to be effective in reducing any bank risk-measure. The limited finding on the effects of restrictions on profit redistribution may be due to a very limited sample, with only a handful of countries having adopted this measure since 2008.

- Other measures: this category of MaPP, which cannot easily be classified, always reduce growth in our three bank vulnerability measures (we did not interact this measure with the strength of the cycle).

The overall results can also be shown graphically. Figure 4 provides three panels depicting the change in the financial risk variable when MaPP are not or are in place. We do this using the regression results of Table 5 when considering no MaPP and all MaPP at the same time and the severity of the cycle by including interaction effects (i.e., comparing columns (1) and (4) for leverage, (5) and (8) for assets, and (9) and (12) for non-core to core). It shows that using MaPP has large effects on non-core to core liabilities growth, reducing this by some 20 percentage points within a year, and maintaining this reduction over a long period. The reduction in leverage and asset growth is more gradual, but still amounts to some 8 and 10 percentage points respectively over a period of 10 years, with most effects felt within the first few years, especially on asset growth.

Next, we repeat the same regressions (except when all MaPP are entered simultaneously) on the impact of various macro-prudential policies during the cycle, but differentiating upswings 
from downswings in the dependent variable. Table 6 reports results. It shows that those policies that seek to mitigate externalities arising primarily in the expansionary phase of the financial cycle are effective in both the upswings and in the downswings. More specifically, MaPP_Expansions systematically and significantly help reduce the growth in leverage, assets and non-core to core liabilities during upswings, with some evidence that they are more effective when the growth of non-core to core liabilities is greater. In the contraction phase side, however, the presence of these tools seems to prevent a rebound in growth in assets and non-core to core liabilities, and actually lead to larger declines in asset and non-core to core liabilities. This suggests that they may be ineffective in fostering a restoration of financial intermediation during adverse conditions. These effects may not surprise. MaPP_Expansion tools like LTV and DTI limits, for example, may actually act perverse during periods of credit contractions and asset prices declines. As borrowers' net worth declines, LTV and DTI limits make it even harder for lenders to extend loans, leading to further declines in house prices, and setting of perverse cycle of event tighter LTV and DTI ratios. Unless the limits are adjusted quickly in a rightly calibrated manner, that is, without unduly risking increasing systemic risks, their effects may be perverse.

On the other hand, those tools which help build buffers in good times, MaPP_Contractions, generally reduce the growth of leverage and assets during upswings, helping even more when their growth is stronger (as the interaction variables with growth are all statistically significant for the three bank risk measures). They also help provide a cushion that alleviates a more severe decline during financial downswings as the sign becomes statistically significant positive for the leverage growth, helping even more when their declines are stronger (as the interaction variables for all three bank risk measures are statistically significant positive). These MaPP tools thus seem to lessen a systemic crunch when the situation warrants by providing buffers so that banks do not reduce leverage, assets, and noncore liabilities as much during bad times. This could be because tools such as reserve requirements seem to provide a liquidity cushion in bad times, while dynamic provisioning, as it builds a buffer during the upturn, supports lending during the downturn. Other tools such as limits on profit redistribution also could have a counter-cyclical buffer effect on banks' willingness to maintain, or at least reduce less, leverage and asset, in bad times at it helps preserve capital.

To investigate whether there are differences between the effectiveness of MaPP depending on country characteristics, we next split countries into groups, first by EMs vs. ACs. As noted, EMs have used MaPP more than ACs have and there are differences among the relative use of specific tools. And EMs differ in many ways from ACs. We may thus expect to find some differences in how MaPP affect financial vulnerabilities. Table 7 provides the regression results. The regression results reflect the differences in usage, as besides LTV, DTI, and credit growth limits, the other MaPP are not used by to ACs (the regressions 
therefore report results as "omitted"). It shows that in general many MaPP affect risks in EMs as many coefficients are statistically significant. For those three MaPP that are used by both ACs and EMs, the results suggest that LTVs are effective in reducing leverage, asset and non-core to core growth, although for ACs only when considering the severity of the cycle for leverage and asset growth. The DTI also affects leverage and non-core to core growth for ACs and growth in all three variables for EMs. Credit growth limits seem of value in ACs for reducing asset growth, and limit growth in all three measures in EMs. Otherwise, regression results suggest some value of reserve requirements, foreign currency limits and dynamic provisioning in limiting some of the risk buildups in EMs' banking systems.

We next split countries by their degree of capital account openness and explore again the differences in regression results. The results (Table 8) reflect again differences in usage as for open capital account countries, many of the MaPP are not used as a tool (and results report this as "omitted"). For those MaPP that were used by both open and closed capital account countries, the results suggest that the MaPP are more effective at curbing bank risk in open capital account countries as the coefficients are generally larger for this group (there are some exceptions to this pattern; for example, LTVs' effectiveness is largely indifferent of the degree of capital account openness). For some MaPP this is to be expected; for example, limits on foreign lending (FC) are likely more important in curbing the growth of non-core to core liabilities in open capital account countries. But it is less obvious why DTI and limits on credit growth (CGs) need to be more effective in open capital account countries as these MaPP are not directly aimed at capital flow related vulnerabilities. It suggests that it is not just the direct exposures from international financial integration that matter to policy makers. Rather, possibly due to their openness, these countries more generally have greater domestic procyclicality and are more exposed to the emergence of systemic risks, for which in turn various MaPP can be effective.

The regression results above provide the statistically significance of effects, but not their economic importance. Looking at economic effects (Table 9, columns 1) suggests that among the various MaPP instruments, the two that appear the most often in the table among three most effective are caps on DTI ratios and limits on credit growth. In terms of frequency of effectiveness across the different aspects of financial sector vulnerability, DTI caps rank the highest. In terms of reducing the growth of leverage and asset specifically, DTI caps are also economically most effective, while LTV caps help best with reduce the growth of non-core to core liabilities. To dampen the pro-cyclicality of non-core to core liabilities, DTI caps are often again most effective in economic terms, while for asset growth reserve requirements and for leverage FC are so (columns 2). In combination with other MaPP (columns 3), reserve requirements seem often to work quite well. 


\section{Conclusions}

Theory supports a role for MaPP in safe-guarding financial stability. MaPP can reduce the buildup of vulnerabilities and can help mitigate the impact of adverse cycles by leading to a greater buildup of buffers. Indeed, our empirical analyses confirm that countries stand to benefit from greater use of MaPP to reduce risk arising in their banking systems. Using a large panel data set of individual bank balance sheets, we find that many MaPP reduce the growth in key variables: leverage, assets, and the non-core to core liabilities ratio. We find in particular caps on debt-to-income ratios to be effective. There is also evidence that the effectiveness of these tools varies by the intensity of the cycle, with a relatively greater impact of most MaPP when changes in financial vulnerabilities are larger.

Some MaPP are more suited to reducing the buildup of vulnerabilities, while others are more geared towards building up buffers. When we differentiate those MaPP thought to be more effective in reducing vulnerabilities, we find that these indeed help reduce risks during upswings. In contraction phases, however, the presence of some of these tools seems to prevent a rebound in the financial variables, suggesting that they may be ineffective in fostering a restoration of financial intermediation during adverse conditions. On the other hand, those tools which help build buffers in good times generally reduce both the level and the growth of bank risk measures during upswings and help provide a cushion that alleviates a more severe crunch during downswings. As such, these tools may be more promising.

There are large differences across countries in the usage of MaPP though, with EMs and countries with closed capital accounts using MaPP relatively more than ACs and closed capital account countries. We find evidence that across a broad range of changes in financial sector vulnerabilities MaPP are more effective at curbing bank risk in EMs. This ought not surprise, given both the more frequent use in these countries and the fact that their financial systems are often simpler, making it more likely that MaPP are effective. We also find that effects of MaPP are quantitatively greater in open capital account countries, even though they are used relatively less in these economies. This could be because the degree of procyclicality is larger for this group, in part due to their greater capital account openness and presumably generally more liberalized financial systems. We also conjecture that there could be both complementary and substitution relationships between MaPP and CFM tools.

Our findings do suggest that the use of MaPP has to be adapted to country circumstances (see also Acharya, 2011, and Shin, 2011 for views on how to adapt MaPP to EMs and developing countries). The ongoing financial crises in ACs and their weak economic performance in contrast to EMs' stable financial systems and continued solid performance, however, may perhaps make one question the view that EMs are more exposed to risks and in need of MaPP. Has indeed the traditional view on EMs being more vulnerable been overtaken by recent developments? Does their better performance make the use of MaPP less necessary? 
Does this reflect structural changes in EMs? Or is it that the use of MaPP explains their better performance?

To address these questions requires one to revisit the debate on the nature of business cycles in EMs and their progress in strengthening their financial sectors and institutional environments, tasks beyond this paper. ${ }^{19}$ Two factors are nevertheless important to note: EMs have indeed become more independent growth poles over the last two decades; and they are institutionally stronger. Due to liberalization and reforms, EMs have now stronger trade and financial linkages, globally and with other EMs. ${ }^{20}$ Their economies are more diversified and in general larger (and contributing more to global growth). And, although with wide variety, EMs today have generally higher growth potentials (Kose and Prasad, 2011). The better growth position of EMs derives in great part from better macroeconomic policies, including stronger fiscal positions and more monetary policy room, due to, among others, more flexible exchange rate regimes and greater use of inflation targeting, and an accumulation of (large) buffers of reserves. This has allowed EMs to employ more flexible policies to respond to shocks, including the recent financial crisis.

In term of changes, most notable is that while their institutional and legal infrastructures still tend to be weaker than ACs, their banking systems are in fact currently ahead of ACs, with generally higher capital ratios, greater liquidity, less leverage and of better quality asset portfolios. Much of this is because regulation and supervision has been strengthened with often notably improved rules for bank resolution. There has been also less concerns about liquidity risks as banks in EMs rely more on core deposit and less on whole-sale funding. Lower public debts and more state-owned banks have also given some headroom and flexibility to deal with shocks such as the 2008-09 global financial crisis and maintain financial intermediation, with less emphasis on deleveraging. To some degree, EMs have become less dependent on foreign finance, shifting away from foreign currency-denominated external debt towards external financing in the forms of FDI and portfolio flows, and much more use of domestic forms of financing. And, as noted, they have also more used macroprudential approaches, with some employing time-varying rules.

\footnotetext{
${ }^{19}$ To address this requires analyzing what has happened before, during and after the global financial crisis. Before the crisis there was much talk of decoupling by EMs from ACs. During the crisis though, EMs were just as affected by the deepest and most synchronized global recession in modern times, and for many EMs, the contraction in output was actually worse than that in the typical AC. Since then, EMs markets have not only bounced back more quickly, but their performance and outlook continues to be better than that of ACs. And financial systems in EMs have withstood the global financial crisis very well.

${ }^{20}$ This also means that there is more commonality in business cycles among EMs. The global factor in explaining cyclical fluctuations has, on average, become less important for all groups, including EMs, while the group-specific factors have become more important, for all groups, including EMs.
} 
Nevertheless, and in spite of these improvements, EMs remain exposed in many ways to various external risks, notably capital flows. Their rapidly changing financial sectors can be risks as well. As banks in EMs increase in size and complexity, cross-sectional risks (e.g., arising from Too Big To Fail and contagion) will likely increase. Changes in financial systems raise, as they did for ACs before the crisis, challenges of oversight, where to draw the perimeter, how to address emerging developments (such as shadow banking systems), and how to regulate and supervise foreign banks. Importantly, domestic financial cycles in EMs are likely to become more important in driving economic outcomes. Many EMs already have had concerns about domestic credit booms, including real estate. At the same time EMs' large exposures and shocks, particularly as regards to capital flows and the degree of euro/dollarization, weaker institutional environment, serious constraints on fiscal and monetary policies and relative more limited head-room remain. So while in some respects, concerns in EMs are becoming similar to those of ACs, EMs should continue to use a different and broad set of policies, including besides monetary, fiscal and micro-prudential policies, MaPP tools. At the same time, their general pragmatic approaches to using these tools can benefit from further research on what are the most effective and efficient approaches. 
Table 1. The Macro-prudential Toolkit

Policy Tool

\begin{tabular}{|c|c|c|c|c|}
\hline $\begin{array}{l}\text { Capital requirements, } \\
\text { rovisioning, surcharges }\end{array}$ & $\begin{array}{l}\text { Restrictions on financial } \\
\text { sector balance sheet } \\
\text { (assets, liabilities) }\end{array}$ & $\begin{array}{l}\text { Restrictions related to } \\
\text { borrower, instrument, or } \\
\text { activity }\end{array}$ & levies & $\begin{array}{l}\text { Other (including } \\
\text { institutional } \\
\text { infrastructure) }\end{array}$ \\
\hline
\end{tabular}

\begin{tabular}{|c|c|c|c|c|c|}
\hline Expansionary phase & $\begin{array}{l}\text { Countercyclical capital } \\
\text { requirements, leverage } \\
\text { restrictions, general } \\
\text { (dynamic) provisioning }\end{array}$ & $\begin{array}{l}\text { Time varying caps/limits on: } \\
\text {-mismatches ( } F X \text {, interest } \\
\text { rate) } \\
\text { - reserve requirements }\end{array}$ & $\begin{array}{l}\text { Time varying } \\
\text { caps/limits/rules on: } \\
\text { - DTI, LTI, LTV } \\
\text { - margins, hair-cuts } \\
\text { - lending to sectors } \\
\text { - credit growth }\end{array}$ & $\begin{array}{l}\text { Ley//tax on specific } \\
\text { assets and/or liabilities }\end{array}$ & $\begin{array}{l}\text { - Accounting (e.g., } \\
\text { varying rules on mark } \\
\text { to market) } \\
\text {-Changes to } \\
\text { compensation, market } \\
\text { discipline, governance }\end{array}$ \\
\hline $\begin{array}{l}\text { Contractionary phase: fire- } \\
\text { sales, credit crunch }\end{array}$ & $\begin{array}{l}\text { Countercyclical capital } \\
\text { requirements, general } \\
\text { (dynamic) provisioning }\end{array}$ & $\begin{array}{l}\text { Liquidity limits (e.g., Net } \\
\text { Stable Funding Ratio, } \\
\text { Liquidity Coverage Ratio) }\end{array}$ & $\begin{array}{l}\text { Adjustment to specific } \\
\text { loan-loss provisioning, } \\
\text { margins or hair-cuts (e.g., } \\
\text { through the cycle, } \\
\text { dynamic) }\end{array}$ & $\begin{array}{l}\text { Ley/tax (e.g., on non- } \\
\text { core liabilities) }\end{array}$ & $\begin{array}{l}\text {-Standardized products } \\
\text {-OTC vs. on exchange } \\
\text {-Safety net (Central } \\
\text { Bank/Treasury } \\
\text { liquidity, fiscal support) }\end{array}$ \\
\hline $\begin{array}{l}\text { Contagion, or shock } \\
\text { propagation from SIFIs or } \\
\text { networks }\end{array}$ & $\begin{array}{l}\text { Capital surcharges linked to } \\
\text { systemic risk }\end{array}$ & $\begin{array}{l}\text { Institution- specific limits on } \\
\text { (bilateral) financial exposures, } \\
\text { other balance sheet } \\
\text { measures }\end{array}$ & $\begin{array}{l}\text { Varying restrictions on } \\
\text { asset composition, } \\
\text { activities (e.g., Volcker, } \\
\text { Vickers) }\end{array}$ & $\begin{array}{l}\text { Tax/lewy varying by } \\
\text { externality (size, } \\
\text { network) }\end{array}$ & $\begin{array}{l}\text { - Institutional } \\
\text { infrastructure (e.g., } \\
\text { CCPs) } \\
\text { - Resolution (e.g., living } \\
\text { wills) } \\
\text { - Varying information, } \\
\text { disclosure }\end{array}$ \\
\hline \multicolumn{6}{|c|}{ Enhancing resilience } \\
\hline \multicolumn{6}{|c|}{ Dampening the cycle } \\
\hline \multicolumn{6}{|c|}{ Dispelling gestation of cycle } \\
\hline
\end{tabular}


Table 2. Detailed Use of Macro-prudential Instruments by Country Classification

\begin{tabular}{ccccccccccc}
\hline \multirow{2}{*}{ Type of Instrument } & $\begin{array}{c}\text { Emerging } \\
\text { Markets }\end{array}$ & $\begin{array}{c}\text { Advanced Closed Capital } \\
\text { Countries }\end{array}$ & $\begin{array}{c}\text { Open Capital } \\
\text { Account }\end{array}$ & $\begin{array}{c}\text { Total Nr. } \\
\text { Account }\end{array}$ & $\begin{array}{c}\text { Total Nr. Total Nr. } \\
\text { Countries }\end{array}$ & $\begin{array}{c}\text { Frequency } \\
\text { of Use }\end{array}$ & $\begin{array}{c}\text { Frequency } \\
\text { of Years }\end{array}$ & $\begin{array}{c}\text { Frequency } \\
\text { country-year }\end{array}$ & $\begin{array}{c}\text { EMs-year } \\
\text { ACs-year }\end{array}$ \\
\hline LTV & $(1)$ & $(2)$ & $(3)$ & $(4)$ & $(5)$ & $(6)$ & $(7)$ & $(8)$ & $(9)$ & $(10)$ \\
\hline DTI & 3 & 2 & 2 & 3 & 5 & 275 & 55 & $16 \%$ & $8 \% *$ & $67 \% *$ \\
CG & 6 & 1 & 4 & 2 & 7 & 315 & 45 & $18 \%$ & $17 \%$ & $9 \%$ \\
FC & 5 & 1 & 4 & 1 & 6 & 228 & 38 & $13 \%$ & $15 \% *$ & $2 \% *$ \\
RR & 7 & 1 & 4 & 3 & 8 & 312 & 39 & $18 \%$ & $21 \% *$ & $5 \% *$ \\
DP & 5 & 0 & 5 & 0 & 5 & 120 & 24 & $7 \%$ & $10 \% *$ & $0 \% *$ \\
CTC & 8 & 1 & 5 & 4 & 9 & 396 & 44 & $23 \%$ & $21 \% *$ & $16 \% *$ \\
PRD & 2 & 0 & 2 & 0 & 2 & 14 & 7 & $1 \%$ & $1 \%$ & $0 \%$ \\
Other & 6 & 0 & 4 & 2 & 6 & 84 & 14 & $5 \%$ & $6 \% *$ & $0 \% *$ \\
\hline Total by classification: & 54 & 7 & 36 & 21 & $/$ & $/$ & $/$ & $100 \%$ & $100 \%$ & $100 \%$ \\
\hline
\end{tabular}

Star* denotes statistical significance at the 5\% level on a two-group ttest. Countries are classified into emerging versus advanced economy countries (source: MSCI 2011), and open versus closed capital account countries (source: Chinn-Ito Index 2008). A country is defined as an open capital account country if its Chinn-Ito index is larger than the global mean in 2005, and a closed capital account country if its Chinn-Ito index is smaller than the global mean in 2005. 
Table 3. Type of Macro-prudential Instruments by Country/Year

\begin{tabular}{|c|c|c|c|c|c|}
\hline Measures & Characteristics & Country & \multicolumn{2}{|c|}{ Classification* } & Period \\
\hline \multicolumn{6}{|l|}{ Aimed at Borrowers } \\
\hline Loan-to-value caps & $\begin{array}{l}\text { Reduces vulnerability arising from highly } \\
\text { geared borrowings }\end{array}$ & $\begin{array}{l}\text { Brazil } \\
\text { France } \\
\text { Mexico } \\
\text { Poland } \\
\text { Spain }\end{array}$ & $\begin{array}{l}\text { Emerging } \\
\text { Advanced } \\
\text { Emeraing } \\
\text { Emerging } \\
\text { Advanced }\end{array}$ & $\begin{array}{c}\text { Closed } \\
\text { Open } \\
\text { Open } \\
\text { Closed } \\
\text { Open } \\
\end{array}$ & $\begin{array}{l}2000-2010 \\
2000-2010 \\
2000-2010 \\
2000-2010 \\
2000-2010\end{array}$ \\
\hline Debt-to-income caps & $\begin{array}{l}\text { Reduces vulnerability arising from highly } \\
\text { geared borrowings }\end{array}$ & $\begin{array}{l}\text { China } \\
\text { Colombia } \\
\text { Hong Kong } \\
\text { Poland } \\
\text { Romania } \\
\text { Serbia } \\
\text { South Korea }\end{array}$ & $\begin{array}{l}\text { Emerqing } \\
\text { Emerqing } \\
\text { Advanced } \\
\text { Emerging } \\
\text { Emerging } \\
\text { Emeraing } \\
\text { Emerging }\end{array}$ & $\begin{array}{l}\text { Closed } \\
\text { Closed } \\
\text { Open } \\
\text { Closed } \\
\text { Open } \\
\text { n/a } \\
\text { Closed }\end{array}$ & $\begin{array}{c}2000-2010 \\
2000-2010 \\
2005-2010 \\
2010 \\
2004-2008 \\
2010 \\
2006-2010\end{array}$ \\
\hline \multicolumn{6}{|c|}{ Aimed at Financial Institutions (Adressing Asset Side) } \\
\hline Credit growth caps & Reduces credit growth directly & $\begin{array}{c}\text { China } \\
\text { Colombia } \\
\text { Malavsia } \\
\text { Niqeria } \\
\text { Serbia } \\
\text { Singapore }\end{array}$ & $\begin{array}{l}\text { Emerging } \\
\text { Emerging } \\
\text { Emeraing } \\
\text { Emeraing } \\
\text { Emerqing } \\
\text { Advanced }\end{array}$ & $\begin{array}{c}\text { Closed } \\
\text { Closed } \\
\text { Closed } \\
\text { Closed } \\
\text { n/a } \\
\text { Open }\end{array}$ & $\begin{array}{c}2000-2010 \\
2000-2010 \\
2000-2010 \\
2010 \\
2008-2010 \\
2010\end{array}$ \\
\hline Foreign currency lending limits & $\begin{array}{l}\text { Reduces vulnerability to fx risks; } \\
\text { Reduces credit growth directly }\end{array}$ & $\begin{array}{l}\text { Arqentina } \\
\text { Austria } \\
\text { Brazil } \\
\text { Hungary } \\
\text { Poland } \\
\text { Romania } \\
\text { Serbia } \\
\text { Turkey }\end{array}$ & $\begin{array}{l}\text { Emeraing } \\
\text { Advanced } \\
\text { Emerging } \\
\text { Emerging } \\
\text { Emerging } \\
\text { Emerqing } \\
\text { Emeraing } \\
\text { Emeraing }\end{array}$ & $\begin{array}{l}\text { Closed } \\
\text { Open } \\
\text { Closed } \\
\text { Open } \\
\text { Closed } \\
\text { Open } \\
\text { n/a } \\
\text { Closed }\end{array}$ & $\begin{array}{c}2003-2010 \\
2008-2010 \\
2000-2010 \\
2010 \\
2006-2010 \\
2005-2010 \\
2008-2010 \\
2009-2010\end{array}$ \\
\hline \multicolumn{6}{|c|}{ Aimed at Financial Institutions (Adressing Liabilities Side) } \\
\hline Reserve requirements & $\begin{array}{l}\text { Reduces vulnerability to funding risks; } \\
\text { Reduces credit growth indirectly }\end{array}$ & $\begin{array}{c}\text { Brazil } \\
\text { Bulqaria } \\
\text { China } \\
\text { Colombia } \\
\text { Russia } \\
\end{array}$ & $\begin{array}{l}\text { Emerqing } \\
\text { Emerqina } \\
\text { Emerqing } \\
\text { Emeraing } \\
\text { Emerging }\end{array}$ & $\begin{array}{l}\text { Closed } \\
\text { Closed } \\
\text { Closed } \\
\text { Closed } \\
\text { Closed } \\
\end{array}$ & $\begin{array}{l}2008-2010 \\
2007-2010 \\
2004-2010 \\
2007-2010 \\
2004-2009 \\
\end{array}$ \\
\hline \multicolumn{6}{|c|}{ Aimed at Financial Institutions (Adressing Bank Buffers) } \\
\hline Dynamic loan-loss provisioning & $\begin{array}{l}\text { Increases resilience and reduces credit } \\
\text { growth indirectly; }\end{array}$ & $\begin{array}{c}\text { Brazil } \\
\text { Bulgaria } \\
\text { Colombia } \\
\text { India } \\
\text { Mongolia } \\
\text { Peru } \\
\text { Russia } \\
\text { Spain } \\
\text { Uruquay }\end{array}$ & $\begin{array}{l}\text { Emeraing } \\
\text { Emerqing } \\
\text { Emerging } \\
\text { Emerging } \\
\text { Emeraing } \\
\text { Emeraing } \\
\text { Emerging } \\
\text { Advanced } \\
\text { Emerging }\end{array}$ & $\begin{array}{c}\text { Closed } \\
\text { Closed } \\
\text { Closed } \\
\text { Closed } \\
\text { Open } \\
\text { Open } \\
\text { Closed } \\
\text { Open } \\
\text { Open }\end{array}$ & $\begin{array}{c}2005-2010 \\
2005-2010 \\
2007-2010 \\
2010 \\
2010 \\
2008-2010 \\
2010 \\
2000-2010 \\
2001-2010\end{array}$ \\
\hline Countorguglinolognital roguiromento & Increases resilience and reduces credit & Brazil & Emerging & Closed & $2007-2010$ \\
\hline Countercyclical capital requirements & growth indirectly; & India & Emerging & Closed & $2008-2010$ \\
\hline Profit distribution restrictions & $\begin{array}{l}\text { Limit dividend payments in good times to } \\
\text { help build up capital buffers in } \\
\text { bad times }\end{array}$ & $\begin{array}{c}\text { Argentina } \\
\text { Colombia } \\
\text { Poland } \\
\text { Romania } \\
\text { Slovakia } \\
\text { Turkey }\end{array}$ & $\begin{array}{l}\text { Emeraind } \\
\text { Emeraina } \\
\text { Emeraing } \\
\text { Emerqing } \\
\text { Emerqina } \\
\text { Emeraina }\end{array}$ & $\begin{array}{c}\text { Closed } \\
\text { Closed } \\
\text { Closed } \\
\text { Open } \\
\text { Open } \\
\text { Closed }\end{array}$ & $\begin{array}{c}2010 \\
2008-2010 \\
2009-2010 \\
2009-2010 \\
2008-2010 \\
2008-2010\end{array}$ \\
\hline \multicolumn{6}{|l|}{ Institutional Infrastructure } \\
\hline $\begin{array}{c}\text { Movina of derivatives to oraanized } \\
\text { Volcker/Vickers tvpes rules } \\
\text { Increase disclosure at svstem level } \\
\text { Market structure measures }\end{array}$ & $\begin{array}{l}\text { Increases transparencv } \\
\text { Reduces (counterpart) risks in capital } \\
\text { Reduces risks of intra-sector spillovers } \\
\text { Enhance market discipline }\end{array}$ & & & & \\
\hline \multicolumn{6}{|l|}{ Other Markelsiruclure measures } \\
\hline $\begin{array}{l}\text { Other macroprudential measures } \\
\text { (countercyclical provisioning, } \\
\text { countercyclical capital, } \\
\text { restrictions on profit distribution, } \\
\text { restrictions on treatment of profits in } \\
\text { regulatory capital) }\end{array}$ & Decrease leverage growth & $\begin{array}{c}\text { Brazil } \\
\text { Colombia } \\
\text { Croatia } \\
\text { Hungary } \\
\text { Indonesia } \\
\text { Malaysia } \\
\text { Norway } \\
\text { Serbia } \\
\text { Slovakia } \\
\text { South Africa } \\
\text { South Korea } \\
\text { Thailand } \\
\text { Uruguay }\end{array}$ & $\begin{array}{l}\text { Emerging } \\
\text { Emerging } \\
\text { Emerging } \\
\text { Emerging } \\
\text { Emerging } \\
\text { Emerging } \\
\text { Advanced } \\
\text { Emerging } \\
\text { Emerging } \\
\text { Emerging } \\
\text { Emerging } \\
\text { Emerging } \\
\text { Emerging }\end{array}$ & $\begin{array}{c}\text { Closed } \\
\text { Closed } \\
\text { Open } \\
\text { Open } \\
\text { Open } \\
\text { Closed } \\
\text { Open } \\
\text { n/a } \\
\text { Open } \\
\text { Closed } \\
\text { Closed } \\
\text { Closed } \\
\text { Open }\end{array}$ & $\begin{array}{c}2007-2010 \\
2000-2010 \\
2007-2010 \\
2010 \\
2005-2010 \\
2000-2010 \\
2010 \\
2008-2010 \\
2008-2010 \\
2008-2010 \\
2008-2010 \\
2008-2010 \\
2008-2010\end{array}$ \\
\hline
\end{tabular}


Table 4A. Summary Statistics

\begin{tabular}{|c|c|c|c|c|c|c|c|c|c|c|c|}
\hline \multirow{2}{*}{ Variable } & \multicolumn{5}{|c|}{ ALL SAMPLE } & \multicolumn{3}{|c|}{ EMs } & \multicolumn{3}{|c|}{ ACs } \\
\hline & Obs. & Mean & Std. Dev. & Min & Max & Obs. & Mean & Std. Dev. & Obs. & Mean & Std. Dev. \\
\hline $\begin{array}{l}\overline{\bar{\sigma}} \overline{\text { Banks }} \\
\bar{\Phi} \text { Years } \\
\text { Oे Country }\end{array}$ & \multicolumn{5}{|c|}{$\begin{array}{l}2826 \text { (unique) } \\
2000-2010 \\
48 \text { (unique) }\end{array}$} & \multicolumn{3}{|c|}{$\begin{array}{l}1172 \text { (unique) } \\
2000-2010 \\
24 \text { (unique) }\end{array}$} & \multicolumn{3}{|c|}{$\begin{array}{l}1654 \text { (unique) } \\
2000-2010 \\
24 \text { (unique) }\end{array}$} \\
\hline Leverage Growth (YoY) & 18799 & $0.3 \%$ & $17.7 \%$ & $-28.3 \%$ & $33.5 \%$ & 7897 & $1.0 \%$ & $19.4 \%$ & 10902 & $-0.2 \%$ & $16.2 \%$ \\
\hline Asset Growth (YoY) & 18930 & $13.4 \%$ & $32.6 \%$ & $-61.4 \%$ & $114.1 \%$ & 7971 & $17.4 \%$ & $37.2 \%$ & 10959 & $10.4 \%$ & $28.5 \%$ \\
\hline Non-core to Core Liab. Growth (YoY) & 9796 & $0.2 \%$ & $49.6 \%$ & $-98.6 \%$ & $113.2 \%$ & 5653 & $1.9 \%$ & $54.7 \%$ & 4143 & $-2.2 \%$ & $41.6 \%$ \\
\hline _ Total Capital Ratio (\%) & 10978 & 16.9 & 8.5 & 8.8 & 42.3 & 4881 & 18.9 & 9.2 & 6097 & 15.3 & 7.4 \\
\hline$\overbrace{\supset}^{\Phi}$ Liquidity Ratio (\%) & 7967 & 0.8 & 0.4 & 0.2 & 1.6 & 4428 & 0.7 & 0.3 & 3539 & 0.8 & 0.4 \\
\hline Stock Market Capital to GDP & 27742 & 0.9 & 0.6 & 0.2 & 2.5 & 11207 & 0.6 & 0.6 & 16535 & 1.0 & 0.6 \\
\hline Leverage Ratio (Total assets/Equity) & 21235 & 15.2 & 12.3 & 2.1 & 52.1 & 8954 & 10.7 & 8.4 & 12281 & 18.6 & 13.6 \\
\hline Ф Assets (mil. USD) & 21243 & 32700 & 66700 & 1300 & 3000000 & 8954 & 11100 & 33300 & 12289 & 48300 & 79300 \\
\hline Equity (mil. USD) & 21237 & 1869 & 3583 & 12 & 14200 & 8954 & 840 & 2033 & 12283 & 2619 & 4226 \\
\hline Non-core Liabilities (mil. USD) & 18636 & 13700 & 31000 & 0 & 2470000 & 8104 & 4203 & 14500 & 10532 & 21000 & 37600 \\
\hline Core Liabilities (M1, mil. USD) & 16309 & 1890000 & 3310000 & 18900 & 10600000 & 9413 & 877000 & 2110000 & 6896 & 3270000 & 4060000 \\
\hline Non-core to Core Liabilities & 19827 & 0.1 & 0.3 & 0 & 5.5 & 6466 & 0.1 & 0.1 & 4573 & 0.0 & 0.1 \\
\hline M1 (mil. USD) & 16309 & 1890000 & 3310000 & 18900 & 10600000 & 10227 & 236000 & 627000 & 7479 & 936000 & 1500000 \\
\hline M2 (mil. USD) & 18274 & 1300000 & 2450000 & 235 & 11000000 & 10524 & 652000 & 1690000 & 7750 & 2190000 & 2990000 \\
\hline Exports (mil. USD) & 31076 & 322860 & 372243 & 0 & 1846750 & 12887 & 176324 & 287 & 18189 & 426682 & 390 \\
\hline Imports (mil. USD) & 31076 & 3254474 & 422976 & 0 & 2556475 & 12887 & 156858 & 237 & 18189 & 444893 & 480 \\
\hline Nominal GDP (mil. USD) & 31076 & 1354845 & 2464482 & 0 & 14500000 & 12887 & 612130 & 932 & 18189 & 1881062 & 3015 \\
\hline$\stackrel{\Phi}{\supset}$ Real GDP (mil. USD) & 31040 & 1280000 & 2410000 & 657 & 13200000 & 12887 & 95700000 & 371000000 & 18189 & 55800000 & 182000000 \\
\hline$\frac{\Phi}{1}$ Central Bank Policy Rate (\%) & 21163 & 6.1 & 5.5 & 0.1 & 21 & 10989 & 11 & 17 & 10174 & 3 & 2 \\
\hline Nominal Effective Exchange Rate & 25578 & 100.1 & 9.1 & 70.4 & 170.0 & 7851 & 102.5 & 12.2 & 17727 & 99.1 & 7.2 \\
\hline Real Effective Exchange Rate & 25039 & 99.8 & 9.3 & 66.7 & 137.2 & 7851 & 102.0 & 12.2 & 17188 & 98.8 & 7.4 \\
\hline ¿ Exchange Rate Classification & 31076 & 2.3 & 1.1 & 1 & 6 & 12887 & 2.4 & 0.9 & 18189 & 2.2 & 1.2 \\
\hline Nominal GDP Growth & 29104 & $7.7 \%$ & $9.3 \%$ & $-9.6 \%$ & $21.5 \%$ & 11377 & $10.9 \%$ & $9.6 \%$ & 17727 & $5.6 \%$ & $8.3 \%$ \\
\hline Real GDP Growth & 31040 & $4.6 \%$ & $10.0 \%$ & $-12.8 \%$ & $18.2 \%$ & 12887 & $4.9 \%$ & $10.9 \%$ & 18153 & $4.3 \%$ & $9.3 \%$ \\
\hline NEER Growth & 25578 & $0.0 \%$ & $5.5 \%$ & $-37.4 \%$ & $22.6 \%$ & 7851 & $-1.2 \%$ & $7.4 \%$ & 17727 & $0.5 \%$ & $4.3 \%$ \\
\hline REER Growth & 25039 & $0.9 \%$ & $5.4 \%$ & $-25.0 \%$ & $25.9 \%$ & 7851 & $1.9 \%$ & $6.9 \%$ & 17188 & $0.4 \%$ & $4.4 \%$ \\
\hline Central Bank Policy Rate Change (\%) & 20942 & $-10.4 \%$ & $55.0 \%$ & $-352.6 \%$ & $207.9 \%$ & 10768 & $-7.9 \%$ & $37.2 \%$ & 10174 & $-13.0 \%$ & $68.9 \%$ \\
\hline Loan-to-Value Ratio & 31076 & 0.36 & 0.43 & 0 & 1 & 12887 & 0.48 & 0.43 & 18189 & 0.28 & 0.42 \\
\hline Loan-to-Value Dummy & 31076 & 0.42 & 0.49 & 0 & 1 & 12887 & 0.57 & 0.50 & 18189 & 0.31 & 0.46 \\
\hline Debt-to-Income Ratio & 31076 & 0.03 & 0.12 & 0 & 0.5 & 12887 & 0.06 & 0.15 & 18189 & 0.01 & 0.08 \\
\hline 음 Debt-to-Income Dummy & 31076 & 0.07 & 0.25 & 0 & 1 & 12887 & 0.13 & 0.33 & 18189 & 0.03 & 0.16 \\
\hline ¿ Credit Growth Caps & 31076 & 0.08 & 0.27 & 0 & 1 & 12887 & 0.19 & 0.39 & 18189 & 0.00 & 0.06 \\
\hline Limits on Foreign Lending & 31076 & 0.08 & 0.27 & 0 & 1 & 12887 & 0.16 & 0.37 & 18189 & 0.02 & 0.13 \\
\hline$\overline{\frac{\pi}{\sigma}}$ Reserve Requirements & 31076 & 0.06 & 0.23 & 0 & 1 & 12887 & 0.14 & 0.34 & 18189 & 0.00 & 0.00 \\
\hline$\sum$ Dynamic Provisioning & 31076 & 0.08 & 0.27 & 0 & 1 & 12887 & 0.11 & 0.31 & 18189 & 0.06 & 0.24 \\
\hline Counter-cyclical Requirements & 31076 & 0.02 & 0.15 & 0 & 1 & 12887 & 0.05 & 0.22 & 18189 & 0.00 & 0.00 \\
\hline Profit Redistribution & 31076 & 0.02 & 0.13 & 0 & 1 & 12887 & 0.04 & 0.19 & 18189 & 0.00 & 0.05 \\
\hline Other MaPP & 31076 & 0.09 & 0.28 & 0 & 1 & 12887 & 0.19 & 0.39 & 18189 & 0.01 & 0.11 \\
\hline
\end{tabular}


Table 4B. Summary Statistics of Banking Variables by Country

\begin{tabular}{|c|c|c|c|c|c|c|c|c|c|c|c|c|c|c|}
\hline \multirow[t]{2}{*}{$\begin{array}{c}\text { IFS } \\
\text { Code } \\
\end{array}$} & \multirow[t]{2}{*}{ Country } & \multirow[t]{2}{*}{ \# Banks } & \multicolumn{2}{|c|}{$\begin{array}{c}\text { Country } \\
\text { Classification }\end{array}$} & \multirow{2}{*}{$\begin{array}{c}\begin{array}{c}\text { Use of } \\
\text { MaPP }\end{array} \\
2000-2010\end{array}$} & \multirow{2}{*}{\multicolumn{2}{|c|}{$\frac{\text { Assets }}{2000-2010}$}} & \multirow{2}{*}{$\begin{array}{l}\text { NCC } \\
(3) \\
\end{array}$} & \multirow{2}{*}{\multicolumn{3}{|c|}{ 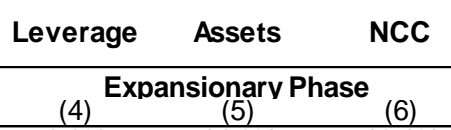 }} & \multirow{2}{*}{\multicolumn{3}{|c|}{$\begin{array}{c}\text { Leverage Assets NCC } \\
\text { Contractionary Phase } \\
(7) \text { (8) }\end{array}$}} \\
\hline & & & & & & & & & & & & & & \\
\hline 111 & United States & 100 & Open & Advanced & No & $-2.1 \%$ & $8.2 \%$ & $2.3 \%$ & $8.8 \%$ & $14.3 \%$ & $13.1 \%$ & $-9.1 \%$ & $-8.1 \%$ & $-15.6 \%$ \\
\hline 112 & United Kingdom & 100 & Open & Advanced & No & $-1.8 \%$ & $6.8 \%$ & n.a. & $17.9 \%$ & $25.4 \%$ & n.a. & $-12.3 \%$ & $-17.5 \%$ & n.a. \\
\hline 122 & Austria & 100 & Open & Advanced & Yes & $-1.3 \%$ & $8.3 \%$ & n.a. & $7.4 \%$ & $21.2 \%$ & n.a. & $-6.7 \%$ & $-9.7 \%$ & n.a. \\
\hline 124 & Belqium & 67 & Open & Advanced & No & $-1.1 \%$ & $4.6 \%$ & n.a. & $10.4 \%$ & $19.0 \%$ & n.a. & $-11.8 \%$ & $-14.5 \%$ & n.a. \\
\hline 132 & France & 100 & Open & Advanced & Yes & $-2.0 \%$ & $6.7 \%$ & n.a. & $10.3 \%$ & $21.3 \%$ & n.a. & $-9.0 \%$ & $-9.3 \%$ & n.a. \\
\hline 134 & Germanv & 100 & Open & Advanced & No & $-1.6 \%$ & $3.7 \%$ & n.a. & $8.4 \%$ & $17.5 \%$ & n.a. & $-7.4 \%$ & $-9.8 \%$ & n.a. \\
\hline 136 & Italy & 100 & Öpen & Advanced & No & $0.7 \%$ & $6.0 \%$ & n.a. & $8.9 \%$ & $21.1 \%$ & n.a. & $-8.1 \%$ & $-14.9 \%$ & n.a. \\
\hline $\begin{array}{l}138 \\
142\end{array}$ & $\begin{array}{l}\text { Netherlands } \\
\text { Norway }\end{array}$ & $\begin{array}{c}58 \\
100\end{array}$ & $\begin{array}{l}\text { Open } \\
\text { Open }\end{array}$ & $\begin{array}{l}\text { Advanced } \\
\text { Advanced }\end{array}$ & $\begin{array}{l}\text { No } \\
\text { Yes }\end{array}$ & $\begin{array}{l}-1.2 \% \\
0.4 \%\end{array}$ & $\begin{array}{c}4.1 \% \\
13.8 \%\end{array}$ & $\begin{array}{l}\text { n.a. } \\
\text { n.a. }\end{array}$ & $\begin{array}{c}12.1 \% \\
8.4 \%\end{array}$ & $\begin{array}{l}19.4 \% \\
21.6 \%\end{array}$ & $\begin{array}{l}\text { n.a. } \\
\text { n.a. }\end{array}$ & $\begin{array}{l}-11.6 \% \\
-7.1 \%\end{array}$ & $\begin{array}{l}-13.9 \% \\
-24.5 \%\end{array}$ & $\begin{array}{l}\text { n.a. } \\
\text { n.a. }\end{array}$ \\
\hline 144 & Sweden & 100 & Open & Advanced & No & $-0.3 \%$ & $14.9 \%$ & $-8.5 \%$ & $6.9 \%$ & $19.3 \%$ & $27.1 \%$ & $-7.3 \%$ & $-14.1 \%$ & $-26.9 \%$ \\
\hline 146 & Switzerland & 100 & Open & Advanced & No & $-1.7 \%$ & $11.2 \%$ & $-4.9 \%$ & $8.2 \%$ & $18.0 \%$ & $17.9 \%$ & $-5.8 \%$ & $-10.9 \%$ & $-17.3 \%$ \\
\hline $\begin{array}{l}156 \\
158\end{array}$ & $\begin{array}{l}\text { Canada } \\
\text { Japan }\end{array}$ & $\begin{array}{c}86 \\
100\end{array}$ & $\begin{array}{l}\text { Open } \\
\text { Open }\end{array}$ & $\begin{array}{l}\text { Advanced } \\
\text { Advanced }\end{array}$ & $\begin{array}{l}\text { No } \\
\text { No }\end{array}$ & $\begin{array}{l}-1.3 \% \\
-2.1 \%\end{array}$ & $\begin{array}{c}12.5 \% \\
4.3 \%\end{array}$ & $\begin{array}{r}1.3 \% \\
-6.5 \%\end{array}$ & $\begin{array}{c}7.0 \% \\
10.3 \%\end{array}$ & $\begin{array}{l}17.4 \% \\
10.7 \%\end{array}$ & $\begin{array}{l}17.6 \% \\
14.6 \%\end{array}$ & $\begin{array}{l}-8.3 \% \\
-10.5 \%\end{array}$ & $\begin{array}{l}-20.6 \% \\
-6.4 \%\end{array}$ & $\begin{array}{l}-21.8 \% \\
-23.3 \%\end{array}$ \\
\hline 172 & Finland & 22 & Open & Advanced & No & $-0.9 \%$ & $7.1 \%$ & n.a. & $10.7 \%$ & $25.2 \%$ & n.a. & $-10.0 \%$ & $-15.8 \%$ & n.a. \\
\hline $17 \overline{8}$ & Ireland & 38 & Open & Advanced & No & $-0.1 \%$ & $0.3 \%$ & n.a. & $15.7 \%$ & $20.1 \%$ & n.a. & $-21.0 \%$ & $-18.4 \%$ & n.a. \\
\hline 182 & Portugal & 39 & Open & Advanced & No & $-0.8 \%$ & $6.3 \%$ & n.a. & $10.1 \%$ & $23.0 \%$ & n.a. & $-13.2 \%$ & $-16.6 \%$ & n.a. \\
\hline $\begin{array}{l}184 \\
186\end{array}$ & $\begin{array}{l}\text { Spain } \\
\text { Turkey }\end{array}$ & $\begin{array}{l}100 \\
59\end{array}$ & $\begin{array}{l}\text { Open } \\
\text { Closed }\end{array}$ & $\begin{array}{l}\text { Advanced } \\
\text { Emerging }\end{array}$ & $\begin{array}{l}\text { Yes } \\
\text { Yes }\end{array}$ & $\begin{array}{l}0.0 \% \\
-0.4 \%\end{array}$ & $\begin{array}{l}5.6 \% \\
14.7 \%\end{array}$ & $\begin{array}{l}\text { n.a. } \\
-6.0 \%\end{array}$ & $\begin{array}{l}8.8 \% \\
15.7 \%\end{array}$ & $\begin{array}{l}20.5 \% \\
24.8 \%\end{array}$ & $\begin{array}{c}\text { n.a. } \\
29.4 \%\end{array}$ & $\begin{array}{l}-7.0 \% \\
-17.9 \%\end{array}$ & $\begin{array}{l}-15.8 \% \\
-23.4 \%\end{array}$ & $\begin{array}{l}\text { n.a. } \\
-39.0 \%\end{array}$ \\
\hline 193 & Australia & 53 & Open & Advanced & No & $-1.7 \%$ & $13.1 \%$ & $-3.1 \%$ & $8.2 \%$ & $28.6 \%$ & $34.1 \%$ & $-9.3 \%$ & $-21.2 \%$ & $-42.4 \%$ \\
\hline $\begin{array}{l}196 \\
199\end{array}$ & $\begin{array}{l}\text { New Zealand } \\
\text { South Africa }\end{array}$ & $\begin{array}{l}17 \\
49\end{array}$ & $\begin{array}{l}\text { Open } \\
\text { Closed }\end{array}$ & $\begin{array}{l}\text { Advanced } \\
\text { Emeraing }\end{array}$ & $\begin{array}{l}\text { No } \\
\text { Yes }\end{array}$ & $\begin{array}{l}-1.8 \% \\
-0.3 \%\end{array}$ & $\begin{array}{l}2.6 \% \\
11.7 \%\end{array}$ & $\begin{array}{l}0.0 \% \\
-30 \%\end{array}$ & $\begin{array}{c}10.7 \% \\
8.9 \%\end{array}$ & $21.7 \%$ & $\begin{array}{l}0.0 \% \\
265 \%\end{array}$ & $\begin{array}{l}-14.3 \% \\
-8.5 \%\end{array}$ & $\begin{array}{l}-25.0 \% \\
-13.4 \%\end{array}$ & $\begin{array}{l}-14.6 \% \\
-35.6 \%\end{array}$ \\
\hline 213 & Argentina & 59 & Closed & Emeraing & Yes & $0.3 \%$ & $7.4 \%$ & $\begin{array}{l}-0.07 \% \\
-8.5 \%\end{array}$ & $20.4 \%$ & $25.8 \%$ & $26.8 \%$ & $\begin{array}{l}-8.5 \% \\
-17.2 \%\end{array}$ & $-20.2 \%$ & $-33.0 \%$ \\
\hline $\begin{array}{l}223 \\
228\end{array}$ & Brazil & $\begin{array}{l}100 \\
27\end{array}$ & Closed & Emerqing & Yes & $2.4 \%$ & $24.3 \%$ & $\begin{array}{l}0.3 \% \\
121 \%\end{array}$ & $18.7 \%$ & $36.4 \%$ & $33.9 \%$ & $-17.0 \%$ & $-35.2 \%$ & $-37.6 \%$ \\
\hline $\begin{array}{l}228 \\
233\end{array}$ & Colombia & 28 & $\begin{array}{l}\text { Upen } \\
\text { Closed }\end{array}$ & $\begin{array}{l}\text { Emeraing } \\
\text { Emeraina }\end{array}$ & $\begin{array}{l}\text { No } \\
\text { Yes }\end{array}$ & $\begin{array}{l}-5.9 \% \\
-0.5 \%\end{array}$ & $\begin{array}{l}14.8 \% \\
13.2 \%\end{array}$ & $\begin{array}{l}-12.1 \% \\
-0.8 \%\end{array}$ & $\begin{array}{l}10.8 \% \\
9.7 \%\end{array}$ & $\begin{array}{l}19.2 \% \\
19.4 \%\end{array}$ & $\begin{array}{l}1.2 \% \\
19.9 \%\end{array}$ & $\begin{array}{l}-14.1 \% \\
-13.1 \%\end{array}$ & $\begin{array}{l}-15.2 \% \\
-18.5 \%\end{array}$ & $\begin{array}{l}-25.1 \% \\
-23.4 \%\end{array}$ \\
\hline 273 & Mexico & 73 & Open & Emerging & Yes & $0.9 \%$ & $13.8 \%$ & $-1.4 \%$ & $18.6 \%$ & $22.1 \%$ & $40.3 \%$ & $-15.8 \%$ & $-16.4 \%$ & $-24.8 \%$ \\
\hline 293 & Peru & 25 & Open & Emerqing & Yes & $-1.4 \%$ & $14.5 \%$ & n.a. & $10.5 \%$ & $21.2 \%$ & n.a. & $-9.4 \%$ & $-12.4 \%$ & n.a. \\
\hline 298 & Uruquay & 23 & Open & Emerging & Yes & $0.0 \%$ & $8.5 \%$ & $-4.3 \%$ & $15.2 \%$ & $17.3 \%$ & $30.7 \%$ & $-19.1 \%$ & $-19.4 \%$ & $-55.6 \%$ \\
\hline $\begin{array}{l}532 \\
534\end{array}$ & $\begin{array}{l}\text { Hona Kona } \\
\text { India }\end{array}$ & $\begin{array}{l}49 \\
91\end{array}$ & $\begin{array}{l}\text { Open } \\
\text { Closed }\end{array}$ & $\begin{array}{l}\text { Advanced } \\
\text { Emerging }\end{array}$ & $\begin{array}{l}\text { Yes } \\
\text { Yes }\end{array}$ & $\begin{array}{l}0.1 \% \\
-0.8 \%\end{array}$ & $\begin{array}{l}8.5 \% \\
148 \%\end{array}$ & $\begin{array}{l}-1.4 \% \\
-8.4 \%\end{array}$ & $\begin{array}{l}8.5 \% \\
8.9 \%\end{array}$ & $16.6 \%$ & $26.0 \%$ & $\begin{array}{l}-9.6 \% \\
-91 \%\end{array}$ & $-13.5 \%$ & $-29.6 \%$ \\
\hline 536 & Indonesia & 51 & Open & Emerging & Yes & $\begin{array}{l}-0.0 \% \\
-1.5 \%\end{array}$ & $\begin{array}{l}14.0 \% \\
16.2 \%\end{array}$ & $\begin{array}{l}-0.4 \% \\
0.0 \%\end{array}$ & $\begin{array}{l}8.9 \% \\
14.1 \%\end{array}$ & $25.2 \%$ & $\begin{array}{l}39.9 \% \\
33.2 \%\end{array}$ & $\begin{array}{l}-9.1 \% \\
-14.0 \%\end{array}$ & $\begin{array}{l}-16.1 \% \\
-11.3 \%\end{array}$ & $\begin{array}{l}-36.4 \% \\
-33.4 \%\end{array}$ \\
\hline 542 & Korea & 42 & Closed & Advanced & Yes & $-5.0 \%$ & $11.6 \%$ & $-0.2 \%$ & $18.2 \%$ & $19.7 \%$ & $32.1 \%$ & $-13.6 \%$ & $-15.6 \%$ & $-19.5 \%$ \\
\hline 548 & Malaysia & 81 & Closed & Emerging & Yes & $-0.9 \%$ & $10.3 \%$ & $-2.4 \%$ & $13.6 \%$ & $17.9 \%$ & $23.8 \%$ & $-13.1 \%$ & $-15.1 \%$ & $-22.6 \%$ \\
\hline 566 & Philippines & 39 & Closed & Emerging & No & $1.3 \%$ & $15.5 \%$ & n.a. & $13.3 \%$ & $20.5 \%$ & n. & $-10.9 \%$ & $-22.5 \%$ & n.a. \\
\hline 576 & Sinqapore & 29 & Open & Advanced & Yes & $-0.3 \%$ & $9.5 \%$ & $0.0 \%$ & $12.0 \%$ & $19.9 \%$ & $0.0 \%$ & $-10.2 \%$ & $-16.1 \%$ & $-35.0 \%$ \\
\hline 578 & & 34 & Closed & Emerqing & $\begin{array}{l}\text { Yes } \\
\text { Yes }\end{array}$ & $-1.2 \%$ & $8.8 \%$ & $\begin{array}{l}-1.1 \% \\
-0.0 \%\end{array}$ & $9.0 \%$ & $16.2 \%$ & $25.0 \%$ & $-11.0 \%$ & $-8.6 \%$ & $-24.9 \%$ \\
\hline $\begin{array}{l}694 \\
918\end{array}$ & $\begin{array}{l}\text { Nigeria } \\
\text { Bulqaria }\end{array}$ & $\begin{array}{l}28 \\
27\end{array}$ & $\begin{array}{l}\text { Closed } \\
\text { Closed }\end{array}$ & & $\begin{array}{l}\text { Yes } \\
\text { Yes }\end{array}$ & $\begin{array}{c}-4.1 \% \\
0.5 \%\end{array}$ & $\begin{array}{l}12.5 \% \\
22.9 \%\end{array}$ & $\begin{array}{l}0.0 \% \\
5.2 \%\end{array}$ & $19.8 \%$ & $28.0 \%$ & $36.7 \%$ & $-22.1 \%$ & -28 & $-37.7 \%$ \\
\hline 922 & $\begin{array}{l}\text { Bussia } \\
\text { Rusia }\end{array}$ & 100 & Closed & Emerging & Yes & $3.8 \%$ & $26.5 \%$ & $\begin{array}{c}5.2 \% \\
\text { n.a. }\end{array}$ & $\begin{array}{l}15.2 \% \\
20.1 \%\end{array}$ & $37.0 \%$ & $40.0 \%$ & $-10.5 \%$ & $-15.2 \%$ & $-31.9 \%$ \\
\hline 924 & China & 100 & Closed & Emeraing & Yes & $2.4 \%$ & $25.6 \%$ & $0.6 \%$ & $\begin{array}{l}20.7 \% \\
14.7 \%\end{array}$ & $\begin{array}{l}40.2 \% \\
290 \%\end{array}$ & $\begin{array}{l}\text { n.a. } \\
457 \%\end{array}$ & $\begin{array}{l}-20.5 \% \\
-20.9 \%\end{array}$ & $\begin{array}{l}-27.2 \% \\
-259 \%\end{array}$ & $\begin{array}{l}\text { n.a. } \\
-396 \%\end{array}$ \\
\hline 935 & Czech Republic & 34 & Open & Advanced & No & $0.0 \%$ & $11.8 \%$ & $-5.9 \%$ & $16.5 \%$ & $23.2 \%$ & $29.1 \%$ & $-12.5 \%$ & $-15.9 \%$ & $-23.3 \%$ \\
\hline 936 & Slovakia & 18 & Open & Advanced & Yes & $1.2 \%$ & $6.8 \%$ & $18.1 \%$ & & $25.3 \%$ & 50. & $-10.4 \%$ & $-10.8 \%$ & $-41.4 \%$ \\
\hline 942 & Serbia & 33 & ' & Emerging & Yes & $5.0 \%$ & $14.9 \%$ & $20.0 \%$ & $16.4 \%$ & $33.1 \%$ & $61.0 \%$ & $-19.6 \%$ & $-19.0 \%$ & $-43.7 \%$ \\
\hline 944 & Hunqary & 28 & Open & Emeraina & Yes & $-0.8 \%$ & $9.6 \%$ & $0.0 \%$ & 12 & 29 & 22. & $-9.2 \%$ & -10 & $-19.2 \%$ \\
\hline 948 & Mongolia & 6 & Open & Emerging & Yes & $8.9 \%$ & $38.4 \%$ & $0.0 \%$ & $19.7 \%$ & $40.8 \%$ & 19. & $-14.7 \%$ & $-30.2 \%$ & $-45.1 \%$ \\
\hline 960 & Croatia & 36 & Open & Emerging & Yes & $3.4 \%$ & $13.4 \%$ & $7.1 \%$ & $13.8 \%$ & $21.9 \%$ & $25.6 \%$ & $-9.4 \%$ & $-9.5 \%$ & $-22.3 \%$ \\
\hline 964 & Poland & 46 & Closed & Emerging & Yes & $-0.7 \%$ & $10.0 \%$ & $-4.8 \%$ & 13 & $25.4 \%$ & 32. & $-10.9 \%$ & $-21.5 \%$ & $-42.1 \%$ \\
\hline 968 & Romania & 28 & Open & Emerging & Yes & 2.6 & $15.7 \%$ & 2.6 & $5 \%$ & $40.5 \%$ & $39.8 \%$ & $-15.2 \%$ & $-19.8 \%$ & $-49.8 \%$ \\
\hline \multirow{5}{*}{\multicolumn{6}{|c|}{$\begin{array}{l}\text { Median (24 emerging countries) } \\
\text { Median ( } 24 \text { advanced countries) } \\
\text { Median ( } 15 \text { closed capital account countries } \\
\text { Median ( } 32 \text { open capital account countries) } \\
\text { Median ( } 30 \text { MaPP users) } \\
\text { Median (14 non-MaPP users) }\end{array}$}} & $\begin{array}{r}0.5 \% \\
-1.0 \%\end{array}$ & $\begin{array}{l}15.7 \% \\
7.8 \%\end{array}$ & $\begin{array}{l}-0.8 \% \\
-0.7 \%\end{array}$ & $\begin{array}{l}14.7 \% \\
10.7 \%\end{array}$ & $\begin{array}{l}26.4 \% \\
20.4 \%\end{array}$ & $\begin{array}{l}31.1 \% \\
21.8 \%\end{array}$ & $\begin{array}{l}-14.3 \% \\
-10.2 \%\end{array}$ & $\begin{array}{l}-19.0 \% \\
-15.0 \%\end{array}$ & $\begin{array}{l}-34.4 \% \\
-25.9 \%\end{array}$ \\
\hline & & & & & & $-0.2 \%$ & $15.3 \%$ & $-2.2 \%$ & $14.6 \%$ & $25.5 \%$ & $31.7 \%$ & $-14.4 \%$ & $-20.5 \%$ & $-32.6 \%$ \\
\hline & & & & & & $-0.4 \%$ & $10.1 \%$ & $-0.9 \%$ & $11.7 \%$ & $22.1 \%$ & $23.3 \%$ & $-11.0 \%$ & $-15.3 \%$ & $-29.8 \%$ \\
\hline & & & & & & $-0.2 \%$ & $12.8 \%$ & $-0.1 \%$ & $13.7 \%$ & $22.0 \%$ & $31.4 \%$ & $-12.1 \%$ & -16 & $-35.3 \%$ \\
\hline & & & & & & $-1.2 \%$ & $60 \%$ & -4.9 & $10.4 \%$ & 10 & 17. & $\%$ & $-15.5 \%$ & $-23.3 \%$ \\
\hline
\end{tabular}


Table 5. Macro-Prudential Policies: 2000-2010

\begin{tabular}{|c|c|c|c|c|c|c|c|c|c|c|c|c|}
\hline \multirow{2}{*}{$\begin{array}{c}\text { Explanatory Variables } \\
\qquad \downarrow\end{array}$} & \multicolumn{4}{|c|}{ Leverage growth } & \multicolumn{4}{|c|}{ Asset growth } & \multicolumn{4}{|c|}{ NCC growth } \\
\hline & (1) & (2) & (3) & $\begin{array}{c}(4) \\
\text { (Simultaneous) }\end{array}$ & (5) & (6) & (7) & $\begin{array}{c}(8) \\
\text { (Simultaneous) }\end{array}$ & (9) & (10) & (11) & $\begin{array}{c}(12) \\
\text { (Simultaneous) }\end{array}$ \\
\hline $\begin{array}{l}\text { Laq Dependent Variable } \\
\text { Laq Real GDP Growth } \\
\text { Lag CB Rate Growth } \\
\text { Lag NEER Growth } \\
\text { FX Rate Arrangement } \\
\text { Laq Capital Adeq. Ratio } \\
\text { Lag Liquidity Ratio } \\
\text { Other MaPP } \\
\text { LTV } \\
\text { LTV X Laq Dependent Var } \\
\text { DTI } \\
\text { DTI X Lag Dependent Var } \\
\text { CG } \\
\text { CG X Laq Dependent Var } \\
\text { FC } \\
\text { FC X Lag Dependent Var } \\
\text { RR } \\
\text { RR X Lag Dependent Var } \\
\text { DP } \\
\text { DP X Lag Dependent Var } \\
\text { PRD } \\
\text { PRD X Lag Dependent Var }\end{array}$ & $\begin{array}{c}-0.118^{\star \star \star} \\
{[0.031]} \\
0.257^{\star \star \star} \\
{[0.055]} \\
-0.018^{\star} \\
{[0.009]} \\
-0.334^{\star} \\
{[0.180]} \\
4.000^{\star \star} \\
{[1.888]} \\
0.013^{\star \star} \\
{[0.005]} \\
0.024 \\
{[0.098]}\end{array}$ & $\begin{array}{c}\text { Yes } \\
\text { Yes } \\
\text { Yes } \\
\text { Yes } \\
\text { Yes } \\
\text { Yes } \\
\text { Yes } \\
\text { Yes } \\
\text { Yes } \\
\text { Yes } \\
\text { Yes } \\
\text { Yes } \\
\text { Yes } \\
\text { Yes } \\
-1.531^{\star \star \star} \\
\lceil 0.391] \\
-0.939^{\star} \\
\lceil 0.403\rceil \\
\\
-5.476^{\star \star} \\
\lceil 2.514\rceil\end{array}$ & $\begin{array}{c}\text { Yes } \\
\text { Yes } \\
\text { Yes } \\
\text { Yes } \\
\text { Yes } \\
\text { Yes } \\
\text { Yes } \\
\text { Yes } \\
\text { Yes } \\
\text { Yes } \\
\text { Yes } \\
\text { Yes } \\
\text { Yes } \\
\text { Yes } \\
-1.433^{\star \star \star} \\
{[0.403]} \\
-0.977^{\star} \\
{[0.486]} \\
-0.683^{\star \star \star} \\
10.2001 \\
-5.905^{\star \star} \\
{[2.496]} \\
-1.638^{\star \star \star} \\
{[0.356]} \\
0.250 \\
{[0.390]} \\
-0.831^{\star \star \star} \\
{[0.205]} \\
-1.722^{\star \star \star} \\
{[0.593]} \\
-6.496^{\star} \\
{[3.7611} \\
-0.151 \\
{[0.133]} \\
-0.581^{\star \star \star} \\
{[0.1661} \\
-0.021 \\
{[0.2301} \\
0.854 \\
{[0.8841} \\
3.188 \\
{[2.2641} \\
2.476^{\star} \\
{[1.446]}\end{array}$ & $\begin{array}{c}\text { Yes } \\
\text { Yes } \\
\text { Yes } \\
\text { Yes } \\
\text { Yes } \\
\text { Yes } \\
\text { Yes } \\
\text { Yes } \\
\text { Yes } \\
\text { Yes } \\
\text { Yes } \\
\text { Yes } \\
\text { Yes } \\
\text { Yes } \\
-0.911^{\star} \\
{[0.810]} \\
-4.845^{\star} \\
{[2.6671} \\
0.918 \\
{[0.789]} \\
\text { (omitted) } \\
\\
-1.596 \\
{[1.469]} \\
-1.472^{\star} \\
{[0.876]} \\
-0.122 \\
{[0.702]} \\
\text { (omitted) } \\
\text { (omitted) } \\
0.946^{\star \star} \\
-0.946^{-} \\
{[0.430]} \\
0.109 \\
{[0.270]} \\
-0.915^{\star} \\
{[0.494]} \\
-2.659 \\
{[3.175]} \\
-1.006 \\
{[1.4171} \\
3.296 \\
{[6.362]}\end{array}$ & $\begin{array}{c}-0.533^{* \star \star} \\
{[0.017]} \\
0.213^{\star \star} \\
{[0.085]} \\
-0.032^{\star \star} \\
{[0.013]} \\
0.743^{\star \star \star} \\
{[0.132]} \\
1.739 \\
{[1.507]} \\
0.010^{\star \star \star} \\
{[0.003]} \\
-0.074 \\
{[0.048]}\end{array}$ & $\begin{array}{c}\text { Yes } \\
\text { Yes } \\
\text { Yes } \\
\text { Yes } \\
\text { Yes } \\
\text { Yes } \\
\text { Yes } \\
\text { Yes } \\
\text { Yes } \\
\text { Yes } \\
\text { Yes } \\
\text { Yes } \\
\text { Yes } \\
\text { Yes } \\
-1.647^{\star \star} \\
{[0.6781} \\
-2.162^{\star \star \star} \\
{[0.774]} \\
\\
-3.915^{\star} \\
{[2.218\rceil}\end{array}$ & $\begin{array}{c}\text { Yes } \\
\text { Yes } \\
\text { Yes } \\
\text { Yes } \\
\text { Yes } \\
\text { Yes } \\
\text { Yes } \\
\text { Yes } \\
\text { Yes } \\
\text { Yes } \\
\text { Yes } \\
\text { Yes } \\
\text { Yes } \\
\text { Yes } \\
-\mathbf{1 . 7 8 1 ^ { \star \star \star }} \\
{[0.661]} \\
-2.333^{\star \star \star} \\
{[0.752]} \\
-0.091 \\
{[0.123]} \\
-4.189^{\star} \\
{[2.214]} \\
0.257 \\
{[0.221]} \\
-0.729^{\star \star \star} \\
{[0.225]} \\
-0.449^{\star \star \star} \\
{[0.116]} \\
-1.656^{\star \star} \\
{[0.706]} \\
3.968 \\
{[3.186]} \\
-0.041 \\
{[0.073]} \\
-0.762^{\star \star \star} \\
{[0.136]} \\
-0.534^{\star \star \star} \\
{[0.124]} \\
-0.745^{\star \star} \\
{[0.362]} \\
-1.24 \\
{[2.103]} \\
2.412 \\
{[1.577]}\end{array}$ & $\begin{array}{c}\text { Yes } \\
\text { Yes } \\
\text { Yes } \\
\text { Yes } \\
\text { Yes } \\
\text { Yes } \\
\text { Yes } \\
\text { Yes } \\
\text { Yes } \\
\text { Yes } \\
\text { Yes } \\
\text { Yes } \\
\text { Yes } \\
\text { Yes } \\
-0.235^{\star} \\
{[0.108]} \\
-0.687 \\
{[1.6941} \\
-1.153 \\
{[2.083]} \\
\text { (omitted) } \\
1.381 \\
{[2.835]} \\
-0.930 \\
{[1.109]} \\
-2.015 \\
{[2.057]} \\
\text { (omitted) } \\
\text { (omitted) } \\
-0.280^{\star \star} \\
{[0.134]} \\
1.497^{\star \star \star} \\
{[0.339]} \\
-1.568^{\star} \\
{[0.830]} \\
-14.262^{\star \star} \\
{[6.235]} \\
0.665 \\
{[1.579]} \\
10.423 \\
{[8.685]}\end{array}$ & $\begin{array}{c}-0.467^{\star \star \star} \\
{[0.018]} \\
0.284^{\star} \\
{[0.161]} \\
-0.113^{\star \star \star} \\
{[0.032]} \\
1.412^{\star \star \star} \\
{[0.270]} \\
0.121 \\
{[0.336]} \\
0.028^{\star} \\
{[0.015]} \\
-0.728^{\star} \\
{[0.389]}\end{array}$ & $\begin{array}{c}\text { Yes } \\
\text { Yes } \\
\text { Yes } \\
\text { Yes } \\
\text { Yes } \\
\text { Yes } \\
\text { Yes } \\
\text { Yes } \\
\text { Yes } \\
\text { Yes } \\
\text { Yes } \\
\text { Yes } \\
\text { Yes } \\
\text { Yes } \\
-10.239^{\star \star \star \star} \\
{[3.494]} \\
-15.854^{\star \star \star} \\
{[5.123]} \\
\\
-3.983^{\star \star \star} \\
{[1.526]} \\
\\
-1.912 \\
{[1.565]} \\
\\
0.498 \\
{[0.325]}\end{array}$ & 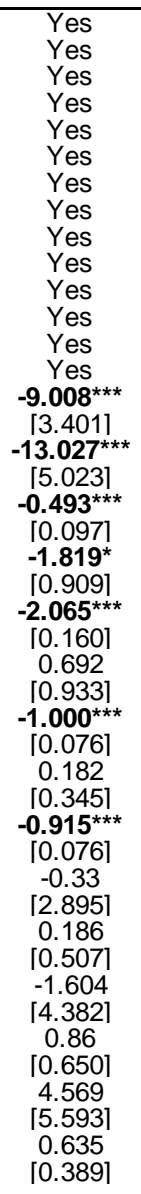 & $\begin{array}{c}\text { Yes } \\
\text { Yes } \\
\text { Yes } \\
\text { Yes } \\
\text { Yes } \\
\text { Yes } \\
\text { Yes } \\
\text { Yes } \\
\text { Yes } \\
\text { Yes } \\
\text { Yes } \\
\text { Yes } \\
\text { Yes } \\
\text { Yes } \\
-11.675^{\star} \\
{[6.122]} \\
-29.251 \\
{[24.872]} \\
-5.885 \\
{[7.295]} \\
\text { (omitted) } \\
4.061 \\
{[10.118]} \\
-3.766 \\
{[2.839]} \\
-8.061^{\star} \\
{[4.606]} \\
\text { (omitted) } \\
\text { (omitted) } \\
\\
-2.252^{\star \star \star \star} \\
\text { [0.591] } \\
-6.786 \\
{[4.326]} \\
-2.669 \\
{[4.036]} \\
5.196 \\
{[67.746]} \\
4.988 \\
{[6.411]} \\
-14.528 \\
{[66.233]}\end{array}$ \\
\hline $\begin{array}{l}\text { Observations } \\
\text { Number of banks }\end{array}$ & $\begin{array}{l}5,676 \\
1,290 \\
\end{array}$ & $\begin{array}{c}4,091 \\
939 \\
\end{array}$ & $\begin{array}{c}4,091 \\
939 \\
\end{array}$ & $\begin{array}{c}4,091 \\
939 \\
\end{array}$ & $\begin{array}{l}5,695 \\
1,292 \\
\end{array}$ & $\begin{array}{c}, 107 \\
940 \\
\end{array}$ & $\begin{array}{c}4,107 \\
940 \\
\end{array}$ & $\begin{array}{l}4,107 \\
940 \\
\end{array}$ & $\begin{array}{l}5,695 \\
1,292 \\
\end{array}$ & $\begin{array}{c}4,107 \\
940\end{array}$ & $\begin{array}{c}4,107 \\
940 \\
\end{array}$ & $\begin{array}{c}4,107 \\
940 \\
\end{array}$ \\
\hline $\begin{array}{l}\text { Notes: The dependent variab } \\
\text { dependent variable, the lag o } \\
\text { arrangements }(0=\text { de facto } \\
\text { countercyclical capital, restr } \\
\text { on credit growth), or FC (limi } \\
\text { shown in one column in (2), } \\
\text { which use lagged differences } \\
\text { fixed effects). Robust standa }\end{array}$ & $\begin{array}{l}\text { bank le } \\
\text { P loga } \\
\text { floating } \\
\text { ? treatn } \\
\text { eign ler } \\
\text { 7), (10) } \\
\text { real G } \\
\text { are in }\end{array}$ & $\begin{array}{l}\text { e growt } \\
\text { ency), } \\
\text { f profit } \\
\text { RR (re } \\
11 \text { ) to } \\
\text { owth as } \\
\text { ets. St }\end{array}$ & $\begin{array}{l}\text { rowth (in } \\
\text {, the lag } \\
r \text { the lagg } \\
\text { in regulat } \\
\text { erve requ } \\
\text { ave space } \\
\text { instrumer } \\
s^{* \star *},{ }^{* *} \text {, }\end{array}$ & $\begin{array}{l}\text { central bank } \\
\text { ak capital ade } \\
\text { apital). The m } \\
\text { nts), DP (dyn } \\
\text { Imns (4), (8) } \\
\text { riables for the } \\
\text { represent sig }\end{array}$ & $\begin{array}{l}\text { rate ch } \\
\text { and le } \\
\text { udentia } \\
\text { rovisio } \\
\text { ?) shov } \\
\text { ident } \\
\text { ce at } t\end{array}$ & $\begin{array}{l}\text { - (ठ)), } \\
\text { e, the } \\
\text { ge ratic } \\
\text { licy me } \\
\text { ), or PF } \\
\text { MaPP } \\
\text { ole. Th } \\
\text {, } 5 \text {, anc }\end{array}$ & $\begin{array}{l}\text { the gro } \\
\text { nd for o } \\
\text { es used } \\
\text { estrictio } \\
\text { ficients } \\
\text { ression } \\
\text { ercent }\end{array}$ & $\begin{array}{l}\text { ate of the non } \\
\text { nacroprudenti } \\
\text { LTV (caps on } \\
\text { profit distrib } \\
\text { aPPs regres } \\
\text { trol for a time } \\
\text { respectively }\end{array}$ & $\begin{array}{l}\text { fective } \\
\text { o-value } \\
\text { Althoud } \\
\text { nultane } \\
\text { fixed } €\end{array}$ & $\begin{array}{l}-(12)) \text {. } \\
\text { hange re } \\
\text { s (coun } \\
\text { TI (caps } \\
\text { gressec } \\
\text { ly. Thes } \\
\text { ts) and }\end{array}$ & $\begin{array}{l}\text { control fo } \\
\text { for foreic } \\
\text { yclical pr } \\
\text { debt-to-ir } \\
\text { e at a tin } \\
\text { e all GM } \\
\text { ndividual }\end{array}$ & $\begin{array}{l}\text { e first lag of the } \\
\text { xchange rate } \\
\text { ioning, } \\
\text { e), CG (limits } \\
\text { MaPPs are } \\
\text { gressions } \\
\text { ds (country }\end{array}$ \\
\hline
\end{tabular}


Table 6. Macro-Prudential Policies over the Cycle

\begin{tabular}{|c|c|c|c|c|c|c|c|c|c|c|c|c|c|c|c|c|c|c|}
\hline \multirow{3}{*}{$\begin{array}{c}\text { Explanatory Variables } \\
\qquad \downarrow\end{array}$} & \multicolumn{6}{|c|}{ Leverage growth } & \multicolumn{6}{|c|}{ Asset growth } & \multicolumn{6}{|c|}{ NCC growth } \\
\hline & \multicolumn{3}{|c|}{$\begin{array}{c}\text { Good times } \\
\text { (Positive leverage growth) }\end{array}$} & \multicolumn{3}{|c|}{$\begin{array}{c}\text { Bad times } \\
\text { (Negative leverage growth) }\end{array}$} & \multicolumn{3}{|c|}{$\begin{array}{c}\text { Good times } \\
\text { (Positive asset growth) }\end{array}$} & \multicolumn{3}{|c|}{$\begin{array}{c}\text { Bad times } \\
\text { (Negative asset growth) }\end{array}$} & \multicolumn{3}{|c|}{$\begin{array}{c}\text { Good times } \\
\text { (Positive NCC growth) }\end{array}$} & \multicolumn{3}{|c|}{$\begin{array}{c}\text { Bad times } \\
\text { (Negative NCC growth) }\end{array}$} \\
\hline & (1) & (2) & (3) & (1) & (2) & (3) & (4) & (5) & (6) & (4) & (5) & (6) & (7) & (8) & (9) & (7) & (8) & (9) \\
\hline \multirow[t]{2}{*}{ Lag Dependent Variable } & $-0.098^{*}$ & Yes & Yes & $-0.175^{\star \star *}$ & Yes & Yes & $-0.517^{\star \star \star}$ & Yes & Yes & $-0.638^{\star * *}$ & Yes & Yes & $-0.386^{\star \star *}$ & Yes & Yes & $-0.442^{\star \star \star}$ & Yes & Yes \\
\hline & {$[0.051]$} & Yes & Yes & {$[0.035]$} & Yes & Yes & {$[0.027]$} & Yes & Yes & {$[0.024]$} & Yes & Yes & {$[0.027]$} & Yes & Yes & {$[0.037]$} & Yes & Yes \\
\hline \multirow[t]{2}{*}{ Lag Real GDP Growth } & $0.203^{\star * *}$ & Yes & Yes & $0.241^{\star * \star}$ & Yes & Yes & $0.438^{* \star *}$ & Yes & Yes & $0.352^{\star \star *}$ & Yes & Yes & 0.080 & Yes & Yes & $0.481^{* *}$ & Yes & Yes \\
\hline & {$[0.064]$} & Yes & Yes & {$[0.068]$} & Yes & Yes & {$[0.074]$} & Yes & Yes & {$[0.088]$} & Yes & Yes & {$[0.268]$} & Yes & Yes & [0.238] & Yes & Yes \\
\hline \multirow[t]{2}{*}{ Lag CB Rate Growth } & $-0.043^{* *}$ & Yes & Yes & $-0.055^{\star * *}$ & Yes & Yes & $-0.145^{\star * *}$ & Yes & Yes & $-0.044^{* * *}$ & Yes & Yes & $-0.103^{\star * \star}$ & Yes & Yes & $-0.098^{* * *}$ & Yes & Yes \\
\hline & {$[0.017]$} & Yes & Yes & {$[0.018]$} & Yes & Yes & [0.023] & Yes & Yes & {$[0.011]$} & Yes & Yes & {$[0.035]$} & Yes & Yes & {$[0.034]$} & Yes & Yes \\
\hline \multirow[t]{2}{*}{ Lag NEER Growth } & $0.464^{* *}$ & Yes & Yes & 0.313 & Yes & Yes & $0.330^{\star *}$ & Yes & Yes & $3.133^{* \star *}$ & Yes & Yes & 0.104 & Yes & Yes & $1.768^{\star * *}$ & Yes & Yes \\
\hline & [0.212] & Yes & Yes & {$[0.282]$} & Yes & Yes & {$[0.137]$} & Yes & Yes & {$[0.189]$} & Yes & Yes & [0.362] & Yes & Yes & [0.342] & Yes & Yes \\
\hline \multirow[t]{2}{*}{ FX Rate Arrangement } & $0.952^{\star *}$ & Yes & Yes & $1.376^{\star * *}$ & Yes & Yes & 1.864 & Yes & Yes & $0.298^{* * *}$ & Yes & Yes & 0.038 & Yes & Yes & -0.306 & Yes & Yes \\
\hline & [0.483] & Yes & Yes & {$[0.464]$} & Yes & Yes & [2.016] & Yes & Yes & {$[0.031]$} & Yes & Yes & {$[0.258]$} & Yes & Yes & {$[0.313]$} & Yes & Yes \\
\hline \multirow[t]{2}{*}{ Lag Capital Adeq. Ratio } & $0.019^{\star * *}$ & Yes & Yes & $-0.016^{\star \star \star}$ & Yes & Yes & -0.006 & Yes & Yes & $0.009^{* \star *}$ & Yes & Yes & -0.002 & Yes & Yes & $0.052^{\star * \star}$ & Yes & Yes \\
\hline & {$[0.005]$} & Yes & Yes & {$[0.005]$} & Yes & Yes & {$[0.004]$} & Yes & Yes & {$[0.001]$} & Yes & Yes & {$[0.008]$} & Yes & Yes & {$[0.016]$} & Yes & Yes \\
\hline \multirow[t]{2}{*}{ Lag Liquidity Ratio } & -0.020 & Yes & Yes & 0.095 & Yes & Yes & -0.057 & Yes & Yes & $-0.121^{\star \star *}$ & Yes & Yes & -0.455 & Yes & Yes & -0.957 & Yes & Yes \\
\hline & {$[0.068]$} & Yes & Yes & [0.122] & Yes & Yes & {$[0.115]$} & Yes & Yes & {$[0.037]$} & Yes & Yes & {$[0.347]$} & Yes & Yes & {$[0.663]$} & Yes & Yes \\
\hline \multirow[t]{2}{*}{ Other MaPP } & & $-0.727^{\star}$ & $-0.652^{\star}$ & & $-1.483^{\star \star \star}$ & $-1.431^{\star \star \star}$ & & $-1.917^{\star}$ & $-2.157^{\star \star}$ & & $-0.987^{\star \star}$ & $-0.405^{\star \star}$ & & $-1.343^{\star \star \star}$ & $-1.494^{\star}$ & & 1.578 & $2.587^{\star \star}$ \\
\hline & & {$[0.666]$} & [0.693] & & {$[0.511]$} & {$[0.510]$} & & {$[1.033]$} & [0.909] & & [0.389] & [0.204] & & [0.403] & [0.742] & & [1.099] & [1.233] \\
\hline \multirow[t]{2}{*}{ Mapp_Expansions } & & $-0.364^{*}$ & $-0.348^{\star}$ & & 0.311 & 0.264 & & $-1.435^{\star}$ & $-1.637^{\star *}$ & & $-0.801^{\star \star *}$ & $-0.538^{\star \star *}$ & & $-1.192^{\star}$ & -0.924 & & $-2.716^{\star *}$ & $-2.288^{\star *}$ \\
\hline & & {$[0.215]$} & {$[0.203]$} & & {$[0.365]$} & {$[0.361]$} & & [0.695] & {$[0.773]$} & & {$[0.186]$} & [0.163] & & {$[0.598]$} & {$[0.916]$} & & [1.111] & {$[1.088]$} \\
\hline \multicolumn{2}{|c|}{ Mapp_Expansions X Lag Dep. Var } & & -0.047 & & & -0.056 & & & 0.158 & & & $-0.400^{* * *}$ & & & $-0.207^{\star *}$ & & & $-0.599^{\star \star *}$ \\
\hline & & & [0.132] & & & {$[0.119]$} & & & {$[0.121]$} & & & {$[0.110]$} & & & {$[0.081]$} & & & [0.083] \\
\hline \multirow[t]{2}{*}{ Mapp_Contractions } & & $-0.346^{\star *}$ & -0.198 & & $0.335^{\star}$ & 0.212 & & $-0.152^{* *}$ & $-0.432^{\star * *}$ & & 0.135 & 0.375 & & 1.479 & 1.009 & & -0.324 & 0.191 \\
\hline & & {$[0.147]$} & {$[0.160]$} & & {$[0.173]$} & [0.394] & & {$[0.065]$} & {$[0.090]$} & & [0.410] & [0.433] & & {$[1.061]$} & {$[1.079]$} & & [0.296] & {$[0.286]$} \\
\hline \multicolumn{2}{|c|}{ Mapp_Contractions X Lag Dep. Var } & & $-0.263^{\star *}$ & & & $0.223^{*}$ & & & $-0.754^{\star \star *}$ & & & $0.527^{\star \star \star}$ & & & $-0.394^{\star * *}$ & & & $0.718^{\star \star \star}$ \\
\hline & & & {$[0.119]$} & & & {$[0.134]$} & & & {$[0.171]$} & & & {$[0.070]$} & & & {$[0.093]$} & & & {$[0.078]$} \\
\hline Observations & 1,166 & 958 & 958 & 1,241 & 1,037 & 1,037 & 1,728 & 1,416 & 1,416 & 697 & 597 & 597 & 906 & 754 & 754 & 888 & 764 & 764 \\
\hline Number of index_number & 509 & 416 & 416 & 532 & 447 & 447 & 590 & 478 & 478 & 419 & 353 & 353 & 377 & 298 & 298 & 390 & 320 & 320 \\
\hline \multicolumn{19}{|c|}{ 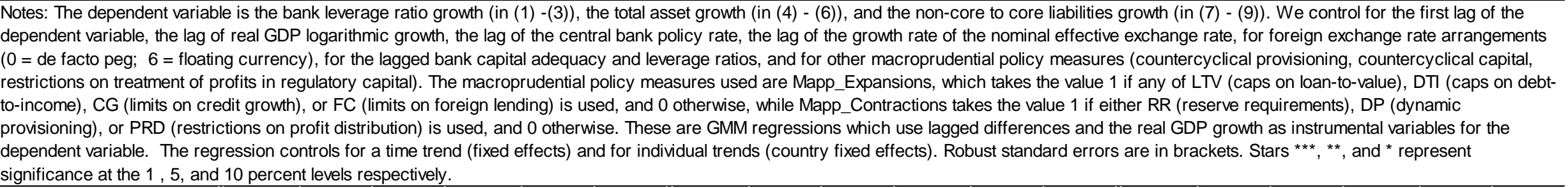 } \\
\hline
\end{tabular}


Table 7. Macro-Prudential Policies: EMs vs. ACs

\begin{tabular}{|c|c|c|c|c|c|c|c|c|c|c|c|c|c|c|c|c|c|c|}
\hline \multirow{3}{*}{$\begin{array}{c}\text { Explanatory Variables } \\
\qquad \downarrow\end{array}$} & \multicolumn{6}{|c|}{ Leverage growth } & \multicolumn{6}{|c|}{ Asset growth } & \multicolumn{6}{|c|}{ NCC growth } \\
\hline & \multicolumn{3}{|c|}{ Advanced Countries } & \multicolumn{3}{|c|}{ Emerging Countries } & \multicolumn{3}{|c|}{ Advanced Countries } & \multicolumn{3}{|c|}{ Emerging Countries } & \multicolumn{3}{|c|}{ Advanced Countries } & \multicolumn{3}{|c|}{ Emerging Countries } \\
\hline & (1) & (2) & (3) & (1) & (2) & (3) & (4) & (5) & (6) & (4) & (5) & (6) & (7) & (8) & (9) & (7) & (8) & (9) \\
\hline Lag Dependent Variable & $-0.153^{* \star *}$ & Yes & Yes & $-0.134^{\star \star \star}$ & Yes & Yes & $-0.456^{\star * *}$ & Yes & Yes & $-0.622^{* * *}$ & Yes & Yes & $-0.254^{\star \star \star}$ & Yes & Yes & $-0.541^{* \star *}$ & Yes & Yes \\
\hline & {$[0.024]$} & Yes & Yes & [0.042] & Yes & Yes & {$[0.018]$} & Yes & Yes & {$[0.020]$} & Yes & Yes & {$[0.030]$} & Yes & Yes & {$[0.025]$} & Yes & Yes \\
\hline Lag Real GDP Growth & $0.329^{\star \star \star}$ & Yes & Yes & $0.442^{\star \star *}$ & Yes & Yes & $0.462^{\star \star \star}$ & Yes & Yes & $0.275^{\star \star \star}$ & Yes & Yes & 0.107 & Yes & Yes & $0.861^{\star}$ & Yes & Yes \\
\hline & {$[0.038]$} & Yes & Yes & {$[0.119]$} & Yes & Yes & {$[0.070]$} & Yes & Yes & {$[0.090]$} & Yes & Yes & [0.089] & Yes & Yes & {$[0.489]$} & Yes & Yes \\
\hline Lag CB Rate Growth & $-0.018^{\star \star}$ & Yes & Yes & $-0.342^{\star \star \star}$ & Yes & Yes & $-0.010^{\star \star}$ & Yes & Yes & $-0.098^{\star}$ & Yes & Yes & $-0.129^{\star \star \star}$ & Yes & Yes & $-0.244^{\star \star \star}$ & Yes & Yes \\
\hline & {$[0.008]$} & Yes & Yes & {$[0.080]$} & Yes & Yes & {$[0.005]$} & Yes & Yes & {$[0.057]$} & Yes & Yes & {$[0.018]$} & Yes & Yes & {$[0.041]$} & Yes & Yes \\
\hline Lag NEER Growth & $-0.215^{\star \star}$ & Yes & Yes & 0.327 & Yes & Yes & $0.651^{\star \star *}$ & Yes & Yes & $0.913^{\star \star \star}$ & Yes & Yes & $0.521^{* \star *}$ & Yes & Yes & $4.037^{\star \star \star}$ & Yes & Yes \\
\hline & {$[0.089]$} & Yes & Yes & {$[0.418]$} & Yes & Yes & {$[0.059]$} & Yes & Yes & {$[0.252]$} & Yes & Yes & {$[0.141]$} & Yes & Yes & {$[0.736]$} & Yes & Yes \\
\hline FX Rate Arrangement & -0.553 & Yes & Yes & -0.047 & Yes & Yes & 0.421 & Yes & Yes & $0.688^{\star \star \star}$ & Yes & Yes & $1.874^{\star}$ & Yes & Yes & $-85.934^{\star \star \star}$ & Yes & Yes \\
\hline & {$[0.544]$} & Yes & Yes & {$[0.246]$} & Yes & Yes & {$[0.380]$} & Yes & Yes & {$[0.086]$} & Yes & Yes & [1.079] & Yes & Yes & [32.742] & Yes & Yes \\
\hline Lag Capital Adeq. Ratio & $0.006^{\star *}$ & Yes & Yes & -0.003 & Yes & Yes & $0.004^{\star}$ & Yes & Yes & $0.006^{\star}$ & Yes & Yes & $0.019^{* *}$ & Yes & Yes & $0.019^{\star \star}$ & Yes & Yes \\
\hline & {$[0.003]$} & Yes & Yes & [0.004] & Yes & Yes & [0.003] & Yes & Yes & [0.003] & Yes & Yes & [0.008] & Yes & Yes & [0.008] & Yes & Yes \\
\hline Lag Liquidity Ratio & -0.038 & Yes & Yes & 0.041 & Yes & Yes & -0.073 & Yes & Yes & $0.642^{\star \star \star}$ & Yes & Yes & $-1.027^{\star \star \star *}$ & Yes & Yes & $-3.165^{\star \star \star}$ & Yes & Yes \\
\hline Other MaPP & {$[0.076]$} & $\begin{array}{c}\text { Yes } \\
-1.301^{\star \star \star} \\
{[0.317]}\end{array}$ & $\begin{array}{c}\text { Yes } \\
-1.297^{\star \star \star} \\
{[0.338]}\end{array}$ & [0.232] & $\begin{array}{c}\text { Yes } \\
0.244 \\
{[0.476]}\end{array}$ & $\begin{array}{c}\text { Yes } \\
-0.606 \\
{[0.443]}\end{array}$ & [0.052] & $\begin{array}{c}\text { Yes } \\
-0.236^{\star \star} \\
{[0.100]}\end{array}$ & $\begin{array}{c}\text { Yes } \\
-0.318^{\star \star} \\
{[0.117]}\end{array}$ & [0.220] & $\begin{array}{c}\text { Yes } \\
-0.695^{*} \\
{[0.380]}\end{array}$ & $\begin{array}{c}\text { Yes } \\
-1.095^{\star \star} \\
{[0.478]}\end{array}$ & [0.230] & $\begin{array}{c}\text { Yes } \\
\text { (omitted) }\end{array}$ & $\begin{array}{c}\text { Yes } \\
\text { (omitted) }\end{array}$ & [0.665] & 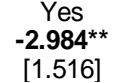 & $\begin{array}{c}\text { Yes } \\
-\mathbf{2 . 8 6 0} \\
{[1.287]}\end{array}$ \\
\hline LTV & & $\begin{array}{l}-1.887 \\
{[1.793]}\end{array}$ & $\begin{array}{l}-1.033 \\
{[2.016]}\end{array}$ & & $\begin{array}{l}-0.003^{*} \\
{[0.000]}\end{array}$ & $\begin{array}{l}-0.696^{\star} \\
{[0.362]}\end{array}$ & & $\begin{array}{c}0.305 \\
{[0.321]}\end{array}$ & $\begin{array}{c}0.474 \\
{[0.336]}\end{array}$ & & $\begin{array}{l}-3.239^{\star \star \star *} \\
{[1.131]}\end{array}$ & $\begin{array}{c}-4.019^{\star \star \star} \\
{[1.206]}\end{array}$ & & $\begin{array}{l}-1.462 \\
{[2.138]}\end{array}$ & $\begin{array}{c}-0.574^{\star \star \star} \\
{[0.185]}\end{array}$ & & $\begin{array}{l}-2.423 \\
{[2.444]}\end{array}$ & $\begin{array}{l}-5.070^{\star *} \\
{[2.411]}\end{array}$ \\
\hline LTV X Lag Dependent Variable & & & $\begin{array}{c}-0.931^{\star \star \star} \\
{[0.242]}\end{array}$ & & & $\begin{array}{c}-0.565^{\star \star \star} \\
{[0.154]}\end{array}$ & & & $\begin{array}{l}-0.140^{\star \star} \\
{[0.068]}\end{array}$ & & & $\begin{array}{c}-0.660^{\star \star \star} \\
{[0.127]}\end{array}$ & & & $\begin{array}{l}-0.368^{\star \star} \\
{[0.170]}\end{array}$ & & & $\begin{array}{c}0.258 \\
{[0.173]}\end{array}$ \\
\hline DTI & & (omitted) & (omitted) & & $\begin{array}{l}-1.748^{*} \\
{[0.965]}\end{array}$ & $\begin{array}{l}-1.051^{*} \\
{[0.509]}\end{array}$ & & (omitted) & (omitted) & & 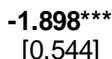 & $\begin{array}{l}-2.134^{\star * *} \\
{[0.596]}\end{array}$ & & (omitted) & (omitted) & & $\begin{array}{l}-0.776^{\star} \\
{[0.881]}\end{array}$ & $\begin{array}{l}-1.686 \\
{[3.133]}\end{array}$ \\
\hline DTI X Lag Dependent Variable & & & $\begin{array}{c}-3.929^{\star \star \star *} \\
{[1.146]}\end{array}$ & & & $\begin{array}{c}-0.717^{\star \star \star} \\
{[0.251]}\end{array}$ & & & (omitted) & & & $\begin{array}{c}-0.560^{\star \star} \\
{[0.221]}\end{array}$ & & & $\begin{array}{l}-2.350^{\star * \star} \\
{[0.563]}\end{array}$ & & & $\begin{array}{l}-0.194^{\star} \\
{[0.097]}\end{array}$ \\
\hline CG & & $\begin{array}{l}-2.640 \\
{[2.663]}\end{array}$ & $\begin{array}{l}-3.162 \\
{[2.989]}\end{array}$ & & $\begin{array}{c}0.305 \\
{[0.297]}\end{array}$ & $\begin{array}{c}0.180 \\
{[0.263]}\end{array}$ & & $\begin{array}{l}-2.723^{\star} \\
{[1.566]}\end{array}$ & $\begin{array}{l}-2.706^{*} \\
{[1.580]}\end{array}$ & & $\begin{array}{l}-0.890^{* \star \star} \\
{[0.171]}\end{array}$ & $\begin{array}{c}-1.098^{\star \star *} \\
{[0.189]}\end{array}$ & & $\begin{array}{l}-11.880^{*} \\
{[7.162]}\end{array}$ & $\begin{array}{l}-5.634 \\
{[5.895]}\end{array}$ & & $\begin{array}{c}-2.444^{\star \star *} \\
{[0.840]}\end{array}$ & $\begin{array}{c}-1.823^{\star \star} \\
{[0.735]}\end{array}$ \\
\hline CG X Lag Dependent Variable & & & $\begin{array}{l}-4.107 \\
{[4.100]}\end{array}$ & & & $\begin{array}{c}-0.490^{\star \star * *} \\
{[0.113]}\end{array}$ & & & $\begin{array}{l}-0.981^{\star} \\
{[0.579]}\end{array}$ & & & $\begin{array}{c}-0.702^{\star \star \star} \\
{[0.115]}\end{array}$ & & & $\begin{array}{l}-0.421 \\
{[0.299]}\end{array}$ & & & $\begin{array}{l}-0.566^{\star \star} \\
{[0.221]}\end{array}$ \\
\hline FC & & (omitted) & (omitted) & & -0.837 & $\begin{array}{r}-0.659 \\
{[0.876]}\end{array}$ & & (omitted) & (omitted) & & $\begin{array}{r}-1.649 \\
-1.826]\end{array}$ & 1.066 & & (omitted) & (omitted) & & $\begin{array}{l}-2.097 \\
01.8851\end{array}$ & $\begin{array}{l}-4.170^{\star *} \\
{[1.948]}\end{array}$ \\
\hline FC X Lag Dependent Variable & & & (omitted) & & & $-1.985^{\star}$ & & & (omitted) & & & $\begin{array}{l}1.061 \\
1.7411\end{array}$ & & & (omitted) & & & 1.300 \\
\hline $\mathrm{RR}$ & & (omitted) & (omitted) & & -0.123 & 0.037 & & (omitted) & (omitted) & & 0.005 & $-0.262^{\star \star \star}$ & & (omitted) & (omitted) & & $-0.017^{\star}$ & $-0.179^{\star *}$ \\
\hline RR X Lag Dependent Variable & & & (omitted) & & [0.082] & $\begin{array}{c}{[0.069]} \\
-0.652^{\star \star \star} \\
{[0.140]}\end{array}$ & & & (omitted) & & [0.051] & $\begin{array}{c}{[0.063]} \\
-0.638^{\star \star *} \\
{[0.120]}\end{array}$ & & & (omitted) & & [0.008] & $\begin{array}{c}{[0.076]} \\
-0.684^{\star \star \star} \\
{[0.113]}\end{array}$ \\
\hline DP & & (omitted) & (omitted) & & -0.094 & 0.117 & & (omitted) & (omitted) & & $-0.246^{\star \star *}$ & $-0.277^{\star \star \star}$ & & (omitted) & (omitted) & & -0.209 & -0.383 \\
\hline DP X Lag Dependent Variable & & & (omitted) & & & $\begin{array}{c}0.151] \\
0.366 \\
{[0.559]}\end{array}$ & & & (omitted) & & {$[0.095]$} & $\begin{array}{c}{[0.096]} \\
0.421 \\
{[0.331]}\end{array}$ & & & (omitted) & & & $\begin{array}{c}{[0.53 /]} \\
0.3 \\
{[0.459]}\end{array}$ \\
\hline PRD & & (omitted) & (omitted) & & 0.535 & 0.763 & & (omitted) & (omitted) & & (omitted) & (omitted) & & (omitted) & (omitted) & & 0.232 & 0.396 \\
\hline PRD X Lag Dependent Variable & & & (omitted) & & & $\begin{array}{l}1.444^{\star \star} \\
{[0.703]}\end{array}$ & & & (omitted) & & & $\begin{array}{c}1.128 \\
{[0.768]}\end{array}$ & & & (omitted) & & & $\begin{array}{c}0.648 \\
{[0.493]}\end{array}$ \\
\hline $\begin{array}{l}\text { Observations } \\
\text { Number of banks }\end{array}$ & $\begin{array}{c}1308 \\
297\end{array}$ & $\begin{array}{c}1175 \\
267\end{array}$ & $\begin{array}{c}1175 \\
267\end{array}$ & $\begin{array}{l}1,124 \\
352\end{array}$ & $\begin{array}{l}820 \\
259\end{array}$ & $\begin{array}{l}820 \\
259\end{array}$ & $\begin{array}{l}1,314 \\
297\end{array}$ & $\begin{array}{l}1,180 \\
267\end{array}$ & $\begin{array}{l}1,180 \\
267\end{array}$ & $\begin{array}{c}1,018 \\
313\end{array}$ & $\begin{array}{l}1,050 \\
318\end{array}$ & $\begin{array}{c}1,050 \\
318\end{array}$ & $\begin{array}{l}936 \\
202\end{array}$ & $\begin{array}{l}936 \\
202\end{array}$ & $\begin{array}{l}936 \\
202\end{array}$ & $\begin{array}{l}604 \\
203\end{array}$ & $\begin{array}{l}604 \\
203\end{array}$ & $\begin{array}{l}582 \\
201\end{array}$ \\
\hline $\begin{array}{l}\text { Notes: The dependent variable } \\
\text { variable, the lag of real GDP los } \\
\text { peg; } 6 \text { = floating currency), for } \\
\text { of profits in regulatory capital). } \\
\text { requirements), DP (dynamic pr } \\
\text { variable. All MaPP tools are re }\end{array}$ & $\begin{array}{l}\text { e bant } \\
\text { thmic } s\end{array}$ & $\begin{array}{l}\text { leverage } \\
\text { owth, the } \\
\text { bank ca } \\
\text { rudentia } \\
\text { and PRD }\end{array}$ & $\begin{array}{l}\text { atio growth } \\
\text { lag of the ce } \\
\text { ital adequac } \\
\text { policy meas } \\
\text { (restrictions }\end{array}$ & $\begin{array}{l}\text { (in (1) - } \\
\text { entral ba } \\
\text { cy and I } \\
\text { sures us } \\
\text { is on pro } \\
n \text { one co }\end{array}$ & $\begin{array}{l}\text { ), the to } \\
\text { k policy } \\
\text { erage ra } \\
\text { d are: L7 } \\
\text { distribut }\end{array}$ & $\begin{array}{l}\text { tal asset } \\
\text { ate chan } \\
\text { tios, and } \\
\text { (caps } \\
\text { on). Thes }\end{array}$ & GN & $\begin{array}{l}\text { - (6)), an } \\
\text { f the growth } \\
\text { croprudent } \\
\text { lue), DTI ( } \\
\text { regression }\end{array}$ & $\begin{array}{l}\text { nd the non-c } \\
\text { th rate of th } \\
\text { tial policy } n \\
\text { (caps on de } \\
\text { ns which us } \\
\text { de time anc }\end{array}$ & $\begin{array}{l}\text { lebt-to } \\
\text { ise lag } \\
\text { nd indi }\end{array}$ & ere & $\begin{array}{l}\text { growth } \\
\text { kchang } \\
\text { clical p } \\
\text { mits on } \\
\text { and th }\end{array}$ & (7) - ( & $\begin{array}{l}\text { or } \\
\text { wh }\end{array}$ & $\begin{array}{l}\text { mits } \\
\text { trum }\end{array}$ & irst lag & the dep & $\begin{array}{l}\text { dent } \\
\text { le facto } \\
\text { tment } \\
\text { reserve } \\
\text { oendent } \\
{ }^{\star \star}\end{array}$ \\
\hline
\end{tabular}


Table 8. Macro-Prudential Policies: Open vs. Closed Capital Account Countries

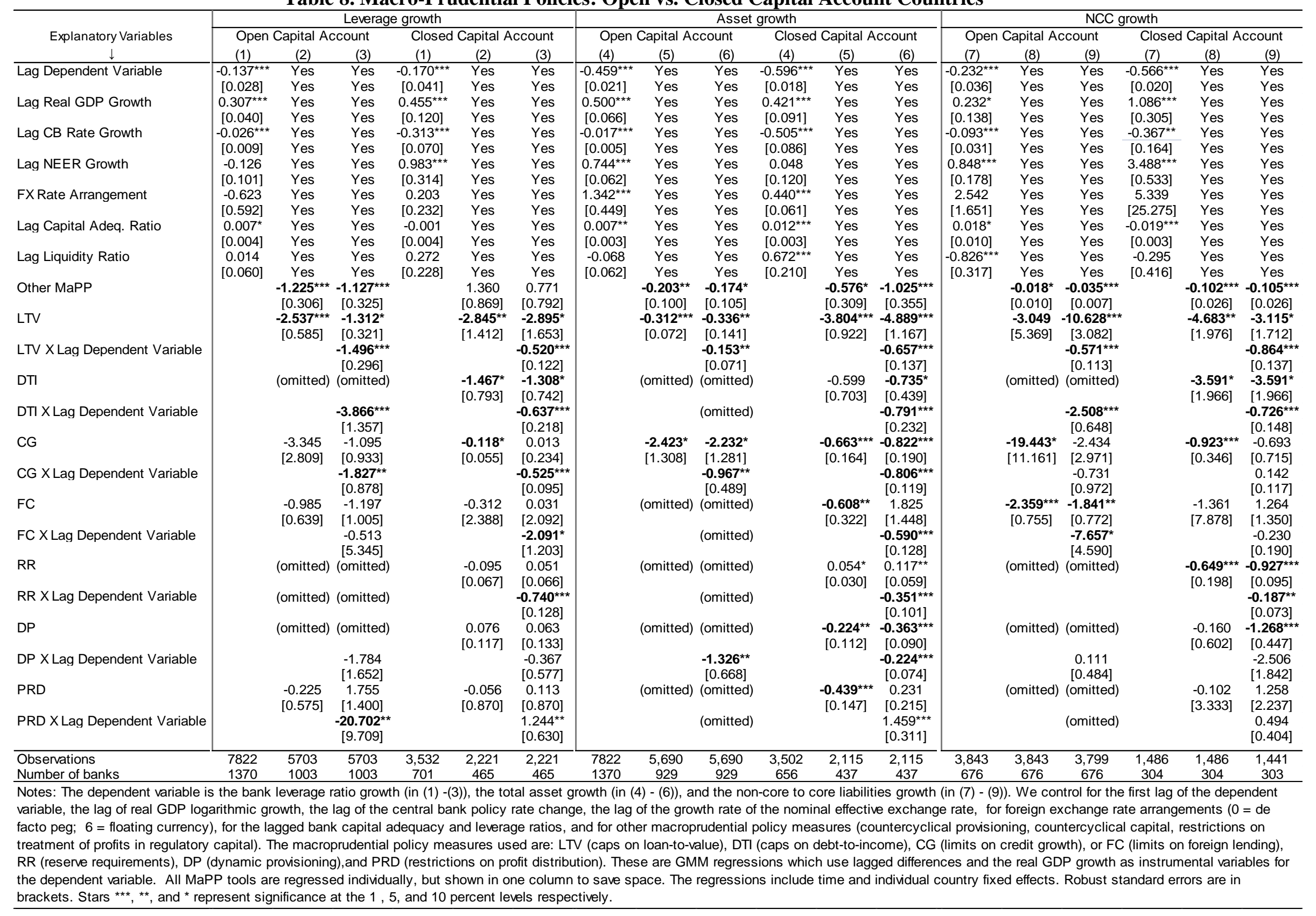


Table 9. The Most Frequently Effective MaPPs

\begin{tabular}{|c|c|c|c|c|c|c|c|c|c|}
\hline \multirow{2}{*}{$\begin{array}{l}\text { Effectiveness in } \\
\text { economic terms }\end{array}$} & \multicolumn{3}{|c|}{ Non-core to core liabilities } & \multicolumn{3}{|c|}{ Bank assets } & \multicolumn{3}{|c|}{ Bank leverage } \\
\hline & $\begin{array}{c}(1) \\
\text { Growth }\end{array}$ & $\begin{array}{c}(2) \\
\text { Pro-cyclicality }\end{array}$ & $\begin{array}{c}(3) \\
\text { Simultaneous } \\
\end{array}$ & $\begin{array}{c}\text { (1) } \\
\text { Growth }\end{array}$ & $\begin{array}{c}\text { (2) } \\
\text { Pro-cyclicality }\end{array}$ & $\begin{array}{c}(3) \\
\text { Simultaneous } \\
\end{array}$ & $\begin{array}{c}\text { (1) } \\
\text { Growth }\end{array}$ & $\begin{array}{c}\text { (2) } \\
\text { Pro-cyclicality }\end{array}$ & $\begin{array}{c}(3) \\
\text { Simultaneous } \\
\end{array}$ \\
\hline 1 & $\begin{array}{c}\text { Loan to Value } \\
\text { Caps (LTV) }\end{array}$ & $\begin{array}{c}\text { Debt to } \\
\text { Income Caps } \\
\text { (DTI) }\end{array}$ & $\begin{array}{l}\text { Credit Growth } \\
\text { Caps (CG) }\end{array}$ & $\begin{array}{c}\text { Debt to } \\
\text { Income Caps } \\
\text { (DTI) }\end{array}$ & $\begin{array}{c}\text { Reserve } \\
\text { Requirements } \\
(\mathrm{RR})\end{array}$ & $\begin{array}{l}\text { Dynamic } \\
\text { Provisioning } \\
\text { (DP) }\end{array}$ & $\begin{array}{c}\text { Debt to } \\
\text { Income Caps } \\
\text { (DTI) }\end{array}$ & $\begin{array}{c}\text { Limits on } \\
\text { Foreign } \\
\text { Lending (FC) }\end{array}$ & $\begin{array}{l}\text { Loan to Value } \\
\text { Caps (LTV) }\end{array}$ \\
\hline 2 & $\begin{array}{c}\text { Debt to } \\
\text { Income Caps } \\
\text { (DTI) }\end{array}$ & $\begin{array}{l}\text { Credit Growth } \\
\text { Caps (CG) }\end{array}$ & $\begin{array}{c}\text { Reserve } \\
\text { Requirements } \\
(\mathrm{RR})\end{array}$ & $\begin{array}{l}\text { Loan to Value } \\
\text { Caps (LTV) }\end{array}$ & $\begin{array}{l}\text { Dynamic } \\
\text { Provisioning } \\
\text { (DP) }\end{array}$ & $\begin{array}{c}\text { Reserve } \\
\text { Requirements } \\
\text { (RR) }\end{array}$ & $\begin{array}{l}\text { Limits on } \\
\text { Foreign } \\
\text { Lending (FC) }\end{array}$ & $\begin{array}{c}\text { Debt to } \\
\text { Income Caps } \\
\text { (DTI) }\end{array}$ & $\begin{array}{l}\text { Credit Growth } \\
\text { Caps (CG) }\end{array}$ \\
\hline 3 & Other MaPP & $\begin{array}{c}\text { Limits on } \\
\text { Foreign } \\
\text { Lending (FC) } \\
\end{array}$ & Other MaPP & $\begin{array}{c}\text { Limits on } \\
\text { Foreign } \\
\text { Lending (FC) }\end{array}$ & $\begin{array}{l}\text { Credit Growth } \\
\text { Caps (CG) }\end{array}$ & Other MaPP & $\begin{array}{l}\text { Loan to Value } \\
\text { Caps (LTV) }\end{array}$ & $\begin{array}{l}\text { Credit Growth } \\
\text { Caps (CG) }\end{array}$ & $\begin{array}{c}\text { Reserve } \\
\text { Requirements } \\
(\mathrm{RR})\end{array}$ \\
\hline
\end{tabular}

$1=$ Most effective in economic terms. $3=$ Less effective in economic terms.

Most frequently effective

2nd most frequently effective

3rd most frequently effective

\section{Figure 1. Factors That Can Lead to Systemic Risks and the Need for MaPP}

Effect of micro prudential policies that are sometimes implemented to address problems of agency and/or collective action frictions at the individual level
Other factors that generate externalities e.g. -strategic complementarity giving rise to correlated behavior

-problems paradoxically arising from successful easing of agency or collective action frictions
Systemic financial vulnerability and instability

Cyclical risks

- During upswings greater risk taking and balance sheet expansion and mismatches such that system as a whole becomes vulnerable even if individual institutions are not.

-Risks materialize during downturns and amplifies the contraction:

Firesales

Credit crunch

Interconnectedness risks

-Spillovers on rest of the system from systemically important institutions or through common exposures

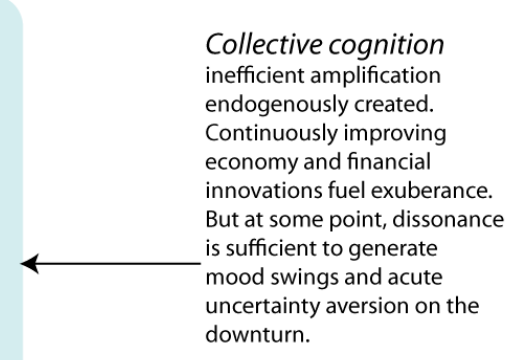

Or

Exogenous shocks--out of the blue positive or negative shocks.

Role for Macroprudential policies

Correct those macro and regulatory policies that contribute to adverse dynamics (e.g. inherent procyclicality of Basel I and II) Limit vulnerability of financial system to adverse dynamics (buffers)

Limit buildup of risks by controlling effects (dampen both asset and business cycles)

Dispel gestation of adverse dynamics in the first place--internalize the externalities (taxes) 
Figure 2. Use of MaPP: ACs vs. EMs and Open vs. Closed Capital Account*

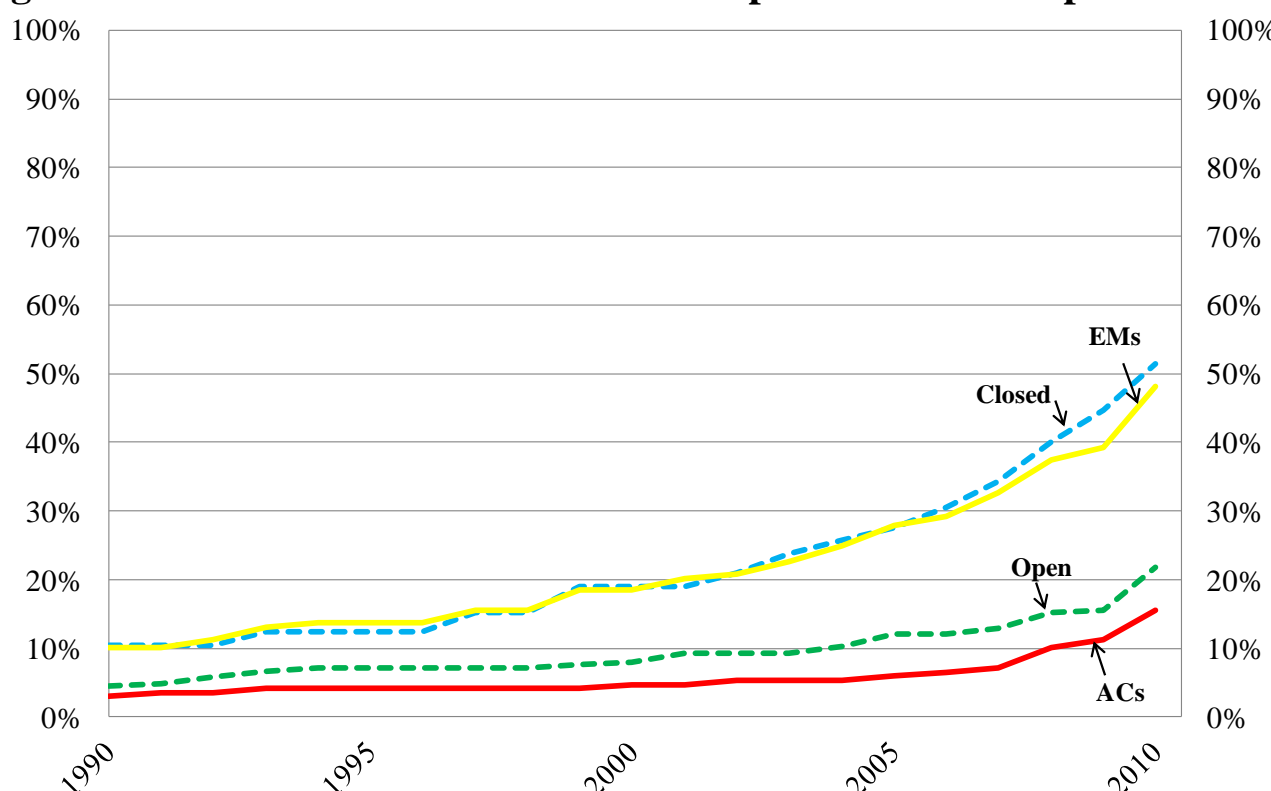

* Index of MaPP usage in emerging markets (EMs), advanced countries (ACs), open capital account economies (Open) and closed capital account economies (Closed). The index represents the percentage of countries in our sample that have used macro-prudential policies. Sources: Lim et al. (2011); Fund staff calculations.

\section{Figure 3. Frequency of Use of Specific Macro-prudential policies (MaPP)}
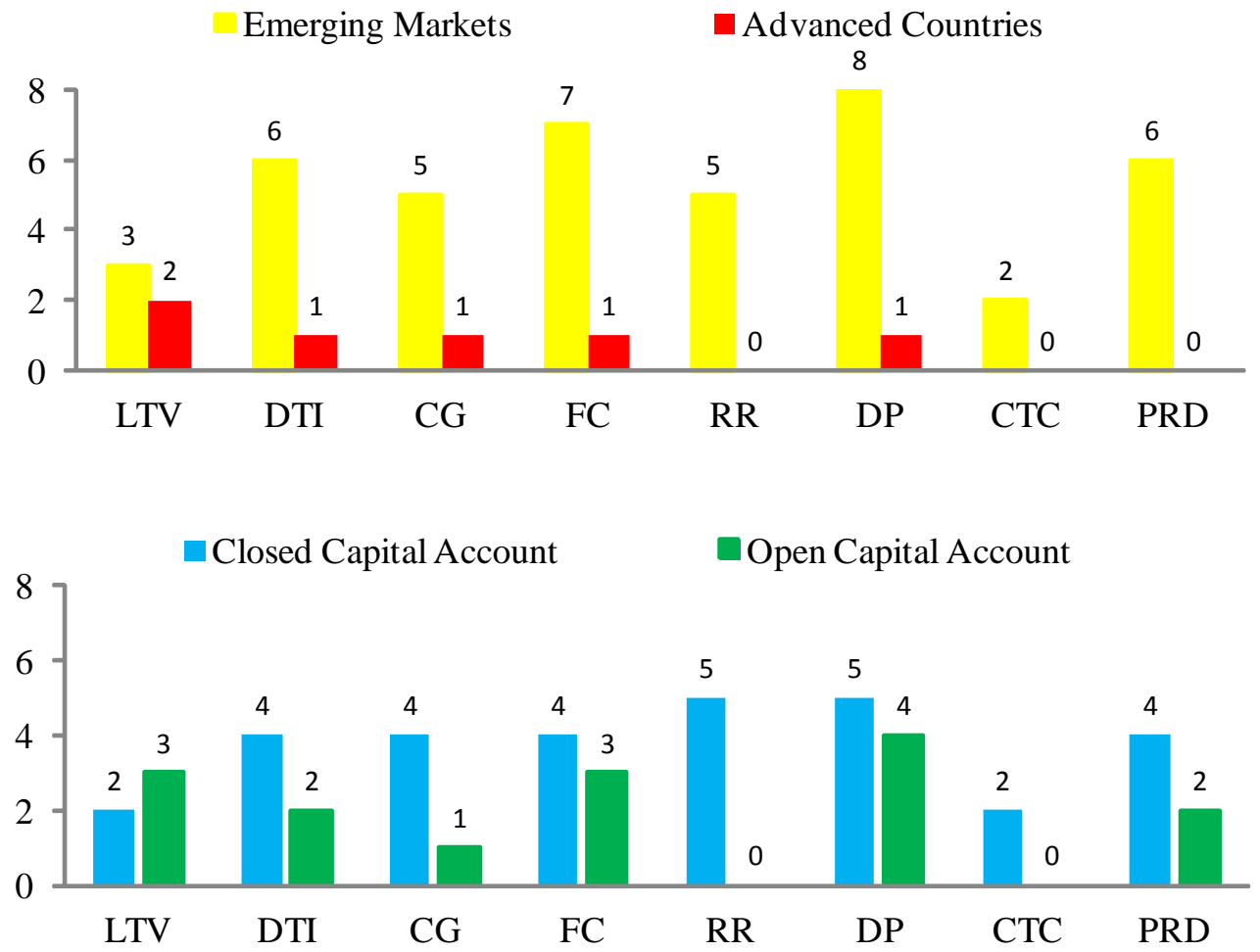

*Each data label represents the number of countries using the specific MaPP. 
Figure 4. Dynamics of Banking System Vulnerabilities With and Without the Presence of Macro-Prudential Policies

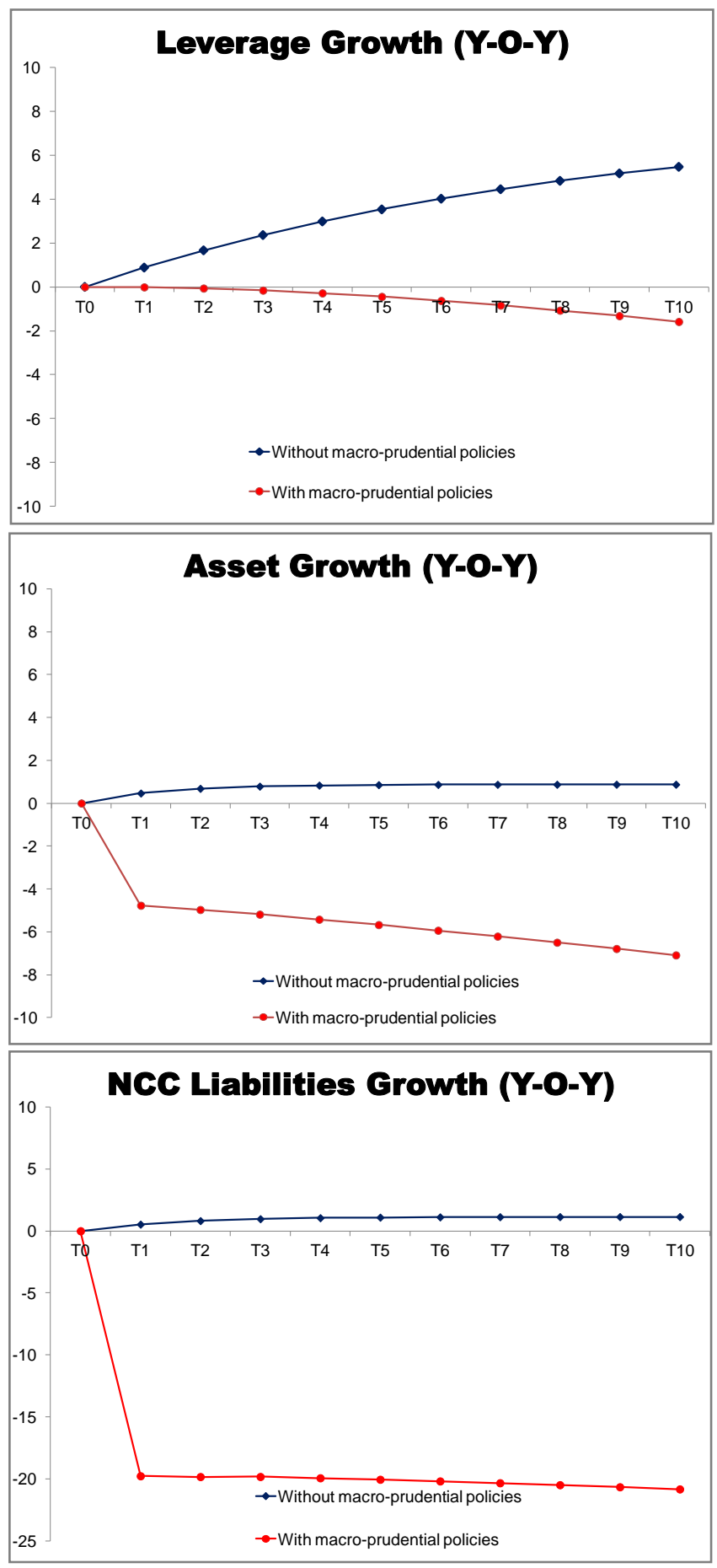




\section{References}

Acharya, Viral, 2011. "Adapting Micro-prudential Regulation for the Emerging Markets", monograph prepared for World Bank, June 2011, New York University.

Adrian, Tobias and Hyun S. Shin, 2010, "Liquidity and Leverage," Journal of Financial Intermediation 19(3), pp. 418-437.

Angelini, P., U. Albertazzi, F. Columba, W. Cornacchia, A. Di Cesare, F. Panetta, A. Pilati, C. Salleo, G. Santini, 2009, "Financial Sector Pro-cyclicality: Lessons from the Crisis” Banca D’Italia Occasional Paper, No. 44. 2009.

Allen, Franklin, and Douglas Gale 2007, Understanding Financial Crises (Clarendon Lect. Finance), Oxford: Oxford Univ. Press.

Allen, Franklin, and Elena Carletti, 2011, "Systemic Risk and Macroprudential Regulation," mimeo, University of Pennsylvania.

Andritzky, Jochen John Kiff, Laura Kodres, Pamela Madrid, Andrea Maechler, Aditya Narain, Noel Sacasa, and Jodi Scarlata, 2012. Policies to Mitigate Procyclicality, IMF Staff Discussion Notes, No.09/059. (Washington: International Monetary Fund).

Bank of England, 2009 “The Role of Macroprudential Policy”. Discussion Paper.

Bank of England, 2011, “Instruments of Macroprudential Policy,” Discussion Paper.

Basel Committee on Banking Supervision, 2010 "A global regulatory framework for more resilient banks and banking systems". Bank for International Settlements.

Bechuk, Lucian and Itay Goldstein, 2011, Self-Fulfilling Credit Market Freezes, Review of Financial Studies, 24, pp. 3519-3555 (2011)

Borio Claudio E.V and William R. White (2003) "Whither Monetary and Financial Stability: the Implications of Evolving Policy Regimes?" - Presentation at the Symposium "Monetary Policy and Uncertainty: Adapting to a changing Economy" Sponsored by the Federal Reserve Bank of Kansas City, Jackson Hole, Wyoming, August.

Bruno, Valentina and Hyun Song Shin. 2011, "Capital Flows, Cross-Border Banking and Global Liquidity," Mimeo, Princeton University, www.princeton.edu/ hsshin/www/capital_flows_global_liquidity.pdf

Brunnermeier, Markus K., Thomas Eisenbach, and Yuliy Sannikov, 2012, Macroeconomics with Financial Frictions: A Survey, In Press (mimeo, Princeton University).

Brunnermeier, Markus K., Charles Goodhart, Andrew Crocket, Avinash Persaud, and Hyun Shin, 2009, The Fundamental Principles of Financial Regulation: 11th Geneva Report on the World Economy. 
Brunnermeier, M. K., and L. H. Pedersen, 2009, "Market Liquidity and Funding Liquidity," Review of Financial Studies, 22(6), 2201-2238.

Claessens, Stijn and Swati R. Ghosh, 2012, "Business and Financial Cycles in Emerging Markets: Lessons for Macro-Prudential Policies," forthcoming in Dongsoo Kang and Hyun Song Shin (Eds.). Financial Regulations on International Capital Flows and Exchange Rates, the East-West Center and the Korea Development Institute.

Claessens, S., M.A. Kose, and M. Terrones, 2011a, "Financial Cycles: What? How? When?" NBER 2010 International Seminar on Macroeconomics, edited by Richard H. Clarida and Francesco Giavazzi. 2011. University of Chicago Press. Pages 303-343.

Claessens, S., M. A. Kose, and M. Terrones, 2011b, "How Do Business and Financial Cycles Interact?" IMF Working Paper, No. 11/88, Washington, D.C. (shorter version published in Journal of International Economics. Vol. 87, Issue 1, May 2012, pp. 178-190).

Chinn, Menzie D. and H. Ito, 2008, "A New Measure of Financial Openness," Journal of Comparative Policy Analysis, Vol. 10:3, pp. 309-22.

Clement, Piet, 2010. "The Term Macroprudential: Origins and Evolution" - BIS Quarterly Review, March

Crowe, C.W., G. Dell'Ariccia, D. Igan, and P. Rabanal, 2011, "How to Deal with Real Estate Booms: Lessons from Country Experiences” IMF Working Paper, No. 11/91.

De la Torre, A., A. Ize, and S. Schmukler, 2012, "Financial Development in Latin America and the Caribbean: The Road Ahead," The World Bank.

De Nicolò, G., G. Favara, and L. Ratnovski, 2012, "Externalities and Macroprudential Policy". IMF Staff Discussion Notes, No.12/05. (Washington: International Monetary Fund).

De Nicolò, G., G. Dell'Ariccia, L. Laeven, and F. Valencia, 2010,“Monetary Policy and Bank Risk Taking” IMF Staff Position Note, No. 10/09.

Dell'Ariccia, Giovanni, Deniz Igan, Luc Laeven, and Hui Tong, 2012, "Policies for Macrofinancial Stability: Options to Deal with Credit Booms," IMF Staff Discussion Note SDN/12/06 (Washington: International Monetary Fund).

Diamond, Douglas W., and Raghuram G. Rajan, , 2001, "Banks, short-term debt and financial crises: theory, policy implications and applications," Carnegie-Rochester Conference Series.

Federico, Pablo, Carlos Vegh, and Guillermo Vuletin, 2012, "Reserve requirement policy over the business cycle," University of Maryland mimeo. 
Geanakoplos, John. 2009. "The Leverage Cycle" in 2009 NBER Macroeconomics Annual 24, edited by Daron Acemoglu and Michael Woodford. University of Chicago Press.

Ghosh, Atish R., Jun Il Kim, Mahvash Saeed Qureshi, and Juan Zalduendo, 2012. "Surges" IMF Working Paper No.12/22

Ghosh, Swati R. 2010. "Dealing with the Challenges of Capital Inflows in the Context of MacroFinancial Links" Economic Premise Note Number 19, The World Bank

Gorton, Gary, 2009, "Slapped in the Face by the Invisible Hand: Banking and the Panic of 2007," Prepared for the Federal Reserve Bank of Atlanta's 2009 Financial Markets Conference: Financial Innovation and Crisis, May 11-13, 2009.

Gorton, Gary, and Andrew Metrick, 2010, "Regulating the Shadow Banking System," Brookings Papers on Economic Activity, Fall, pp. 261-97.

Hahm, Joon-Ho, Hyun Song Shin, and Kwanho Shin. 2011, "Non-Core Bank Liabilities and Financial Vulnerability," paper presented at Federal Reserve/JMCB joint conference, September. princeton.edu/ hsshin/www/noncore.pdf

Hanson, Samuel, Anil Kayshap, and Jeremy Stein, 2011, “A Macroprudential Approach to Financial Regulation," Journal of Economic Perspective, Vol. 25, No. 1, Winter, pp. 3-28.

Igan, Deniz, and Heedon Kang, 2011, "Do Loan-to-Value and Debt-to-Income Limits Work? Evidence from Korea," IMF Working paper No. 11/297 (Washington: International Monetary Fund)

Jiménez, Gabriel, Steven R. G. Ongena, Jose-Luis Peydro, and Jesus Saurina Salas, 2012, "Macroprudential Policy, Countercyclical Bank Capital Buffers and Credit Supply: Evidence from the Spanish Dynamic Provisioning Experiments," European Banking Center Discussion Paper No. 2012-011.

International Monetary Fund, 2010a, "A Fair and Substantial Contribution by the Financial Sector: Report to the G20" (Washington, D.C.: International Monetary Fund)

_ _ 2011a, "Macroprudential Policy: An Organizing Framework," Board Paper, April (Washington: International Monetary Fund).

— , 2011b, "Recent Experiences in Managing Capital Inflows-Cross-Cutting Themes and Possible Guidelines," IMF Policy Paper, April (Washington: International Monetary Fund).

Kose, M. Ayhan and Eswar Prasad, 2010, Emerging Markets: Resilience and Growth Amid Global Turmoil, Brookings Institution Press, 2010.

Lim, C.F. Columba, A. Costa, P. Kongsamut, A. Otani, M. Saiyid, T. Wezel, and X. Wu, 2011, "Macroprudential Policy: What Instruments and How to Use Them? Lessons 
from Country **Experiences," IMF Working Paper 11/238 (Washington: International Monetary Fund).

Ostry, Jonathan David, Atish R. Ghosh,, Karl Friedrich Habermeier, Luc Laeven, Marcos Chamon, Mahvash Saeed Qureshi, and Annamaria Kokenyne, 2011, "Managing Capital Inflows: What Tools to Use?" IMF Staff Discussion Note 11/06 (Washington: International Monetary Fund).

Palley, Thomas, 2004. "Asset-based Reserve Requirements: Reasserting Domestic Monetary Control in an Era of Financial Innovation and Instability Review of Political Economy, Vol. 16, No. 1, 43-58.

Rajan, Raghuram G., 1994, "Why Bank Credit Policies Fluctuate: A Theory and Some Evidence," Quarterly Journal of Economics, Vol. 109, pp. 399-441.

Schoenmaker, Dirk, and Peter J. Wierts, 2011, "Macroprudential Policy: The Need for a Coherent Policy Framework," DSF Policy Paper 13 (Amsterdam, The Netherlands: Duisenberg School of Finance).

Shin, Hyun Song, 2008, Risk and Liquidity, Clarendon Lectures in Finance, Oxford University Press

Shin, Hyun Song, 2010, "Non-Core Liabilities Tax as a Tool for Prudential Regulation". Policy Memo. http://www.princeton.edu/ hsshin/www/NonCoreLiabilitiesTax.pdf

Shin, Hyun Song, 2011, "Adapting Macroprudential Approaches to Emerging and Developing Economies," Report commissioned by the World Bank's Poverty Reduction and Economic Management (PREM) Network, May (Washington: The World Bank).

Shin, Hyun Song. 2012, "Global Banking Glut and Loan Risk Premium," 2011 MundellFleming Lecture, IMF Economic Review 60 (July): 155-192.

Vandenbussche, Jérôme, Ursula Vogel, and Enrica Detragiache, 2012, Macroprudential Policies and Housing Prices-A New Database and Empirical Evidence for Central, Eastern, and Southeastern Europe, IMF Working Paper, Washington, D.C.

White, William R. 2006, "Procyclicality in the financial system: do we need a new macrofinancial stabilisation framework?," BIS Working Papers, no 193, January. 